\title{
A memória do tempo de cativeiro no Maranhão*
}

\section{Matthias Röhrig Assunção ${ }^{* *}$}

"Cantor, tu larga essa mania

De querer surrar os cantador

Que a pessoa maluca

Que tinha no Maranhão

Era Ana Jansen

Ela já morreu

No tempo da escravidão

A alma dela hoje vive arrependida

Implorando a salvação

Os anjos lá no céu

Todos se reuniram

Lamentaram a situação

Que para ela não tem perdão.”

João Chiador

Boi da Maioba

"A mulher do padeiro

Trabalhava noite e dia

De noite pisava uma carga de arroz

E de dia fazia renda."

\footnotetext{
* Artigo recebido e aprovado para publicação em março de 2010.

** Senior Lecturer, Department of History, Essex University, Inglaterra, : assuncao@essex. ac.uk
} 
Cantiga recolhida com Raimunda Pio

Fazendinha/Santa Quitéria

O artigo é baseado em entrevistas feitas com pessoas na sua maioria idosas em vários municípios do nordeste do Maranhão, em 1982. Documenta a memória oral da escravidão de indivíduos e comunidades afrodescendentes e mestiças. Os depoimentos fornecem informações preciosas sobre o trabalho quotidiano, a violência sofrida pelos escravizados e as várias maneiras de resistir aos senhores e feitores. São analisadas algumas categorias-chaves desta memória oral, como a dicotomia entre o "bom" senhor e o "ruim" ou "malvado". O texto destaca algumas singularidades da escravidão dos africanos e de seus descendentes no Maranhão.

Palavras-chaves: escravidão, memória, identidade, narrativa, história oral, resistência.

\section{Memory of the slavery era in Maranhão}

The article is based on interviews of mainly elderly people in various municipalities of north-eastern Maranhão in 1982. It documents the oral memory of slavery imposed on Afro-descendents and mixed-race individuals and communities. The testimonies provide crucial information about every day labour conditions, the violence endured by the enslaved, and the various ways of resistance. The text also analyses some key categories of this oral memory, such as the 'good' and the 'bad' owner dichotomy. It highlights certain peculiarities of the slavery of Africans and their descendents in the former province of Maranhão.

Keywords: Slavery, memory, identity, story, oral history, resistance.

\section{La memorie du temps de la servitude au Maranhão}

L'article reproduit des extraits d'interviews avec des personnes, en général âgées, de plusieurs municipalités du Nord-est de l'État du Maranhão, en 1982. Il documente la mémoire orale de l'esclavage recueilli auprès d'individus et de communautés noires ou métisses. Les témoignages fournissent des informations précieuses sur le travail quotidien, la violence à laquelle les captifs furent soumis ainsi que leurs différentes façon de résister aux propriétaires et aux "feitores" (contremaîtres ou surveillants). Suit une analyse de quelques catégories-clés de la mémoire orale, comme la dichotomie entre le « bon» et «mauvais » ou «méchant» seigneur. Le texte montre ainsi quelques singularités de l'esclavage des africains et de leurs descendants dans le Maranhão. Motsclés: esclavage, mémoire, identité, récit, histoire orale, résistances. 
A escravidão africana teve no Maranhão alguns aspectos singulares. Até 1750 o número de africanos escravizados foi insignificante. A Companhia Geral do Comércio do Grão-Pará e Maranhão obteve o monopólio do tráfico da Coroa, e trouxe 12 mil africanos para a capitania entre 1755 e 1778. Com o subsequente desenvolvimento das fazendas de algodão e arroz, fomentado pela crescente demanda europeia por esses produtos, vieram mais $100 \mathrm{mil}$ africanos, sobretudo de Guiné, Dahomey e Angola. ${ }^{1}$ Desta maneira, às vésperas da Independência, o Maranhão era a província brasileira com maior percentual de escravizados (78 mil, ou 55\% da população). Depois da crise de 1817, no entanto, o algodão maranhense encontrou dificuldades crescentes no mercado mundial. Por isso o tráfico transatlântico de escravos para a província se tornou inexpressivo bem antes de 1850. Crises econômicas e políticas - a guerra da Independência (1822-23) e a Balaiada (1838-41), que se desenrolaram na principal região produtora de algodão - contribuíram para abalar o poder econômico dos senhores. A inserção da sociedade escravagista no meio amazônico - a maior parte do norte da província era coberta por densas matas - combinada com esse desenvolvimento tardio, curto e intensivo, pode explicar alguns dos traços particulares do cativeiro maranhense. Junto com o Pará, o Maranhão gozava de péssima reputação entre escravos e senhores alhures. Ao ponto de a venda para o Maranhão ser até uma ameaça para punir escravos desobedientes em outras províncias. ${ }^{2}$ Não há ainda uma explicação bem estabelecida na historiografia a respeito dessa imagen negativa. Contemporâneos viam a causa nas péssimas condições de trabalho. ${ }^{3}$ Outra razão certamente residia na proliferação, por todo o território da província, de doenças endêmicas como "sezões" (malária). Finalmente, o processo de apropriação de terra se deu de maneira distinta no escravismo maranhense. Resultou na ocupação de muitas

\footnotetext{
${ }^{1}$ Matthias Röhrig Assunção, Pflanzer, Sklaven und Kleinbauern in der brasilianischen Provinz Maranhão, 1800-1850, Frankfurt, Vervuert, 1993, p. 78-80.

${ }^{2}$ Para a péssima reputação do Maranhão ver, entre outros, Bernardo Gama, "Informação sobre a Capitania do Maranhão, dada em 1813 ao Chanceller Antônio Rodrigues Velloso". In: Projeção, Suplemento Cultural, São Luís, março 1981, p. 14; Octávio da Costa Eduardo, The Negro in Northern Brazil. A Study in Acculturation, Seattle and London, University of Washington Press, 1966, p. 16; e Manoel Correia de Andrade, Dinâmica de povoamento e a ocupação do espaço geográfico no Maranhão”, Estudos universitários, Recife, 7, 2/3 (1967), p. 46. ${ }^{3}$ Ver, por exemplo, João António Garcia d'Abranches, Espelho crítico-político da província do Maranhão, dividido em duas partes: [...] por um habitante da mesma província, Lisboa, Tipografia Rollandiana, 1822, p. 40-41.
} 
terras por ex-escravos antes e depois da Abolição, as chamadas 'terras de preto', mais numerosas no Maranhão do que em qualquer outro estado. ${ }^{4}$

Não pretendo aqui refazer a história da escravidão africana no Maranhão, sobre a qual existem, além de vários trabalhos, muitos documentos ainda inexplorados. ${ }^{5}$ Quero apenas dar voz à memória oral, para mostrar que a memória popular também tem sua própria visão, incompleta e fragmentada, evidentemente, mas não mais deformante do que a dos historiadores que falam a partir da casa-grande. Acredito que a memória oral nos aproxima da experiência de vida, e da visão do mundo dos próprios escravizados, como eles e elas a transmitiram a seus filhos, netos e tataranetos, e também a algumas outras pessoas. É sabido que registros sistemáticos de memória oral da escravidão foram feitos nos Estados Unidos a partir da década de 1930. No Brasil, no entanto, os primeiros registros dessa natureza datam apenas das décadas de 1980 e $90 .^{6}$

\footnotetext{
${ }^{4}$ Sobre essa categoria, ver Alfredo Wagner Berno de Almeida, "Terras de Preto, Terras de Santo, Terras de Índio - uso comum e conflito", Cadernos do NAEA (Belém), 10, 1989, p. 163-196.

${ }^{5}$ Além dos citados ver: Alfredo Wagner Berno de Almeida, A ideologia da decadência: leitura antropológica a uma história da agricultura do Maranhão, São Luís, IPES, 1983; Maria Januária Vilela Santos, A Balaiada e a insurreição de escravos no Maranhão, São Paulo, Ática, 1983; Jalila Ayoub Jorge Ribeiro, A desagregação do sistema escravista no Maranhão, 1850-1888, São Luís, SIOGE, 1990; Maria Raimunda Araújo, Insurreição de Escravos em Viana - 1867, São Luís, SIOGE,1994; Regina Helena Martins de Faria, Trabalho escravo e trabalho livre na crise da agroexportação escravista no Maranhão, Monografia do Curso de Especialização em História Econômica Regional, Universidade Federal do Maranhão, mimeo, 1998; Matthias Röhrig Assunção, "Exportação, mercado interno e crises de subsistência numa província brasileira: o caso do Maranhão, 1800-1850”, Estudos Sociedade e Agricultura, 14 (abril), 2000, p. 32-71; Josenildo de Jesus Pereira, Na fronteira do cárcere e do paraíso: um estudo sobre as práticas de resistência escrava no Maranhão oitocentista. Dissertação de Mestrado, Programa de Pós-Graduação em História, Pontifícia Universidade Católica de São Paulo, São Paulo, 2001; Judith Carney, "With grains in her hair: rice in colonial Brasil", Slavery and Abolition, vol. 25, no. 1, 2004, p. 1-27; Flávio dos Santos Gomes, A hidra e os pântanos. Quilombos e mocambos no Brasil (Séculos XVII-XIX), São Paulo, UNESP/Polis, 2005; Cristiane Pinheiro Santos Jacinto, Laços \&̈ Enlaces: relações de intimidade de sujeitos escravizados. São Luís - Século XIX, São Luís: Editora da UFMA, 2008.

${ }^{6}$ Mário Maestri Filho, Depoimentos de escravos brasileiros, São Paulo, Ícone, 1988; Agostinho Mario Dalla Vecchia, Os filhos da Escravidão. Memórias de descendentes de escravos da região meridional do Rio Grande do Sul, Pelotas, Editora Universitária UFPEL, 1993; Maria de Lourdes Janotti e Zita de Paula Rosa, "Memory of Slavery in Black Families of São Paulo, Brazil". In: Daniel Bertaux e Paul Thompson (orgs.), Between Generations. Family Models, Myths, and Memories, Oxford University Press, 1993; Ana Lugão e Hebe Mattos, Memórias do Cativeiro. Família, trabalho e cidadania no pós-abolição, Rio de Janeiro, Civilização Brasileira, 2005.
} 
Os depoimentos que seguem foram obtidos durante um trabalho de campo no Maranhão oriental, entre janeiro e outubro de 1982, e publicados pela primeira vez em 1988. ${ }^{7}$ Escolhi esta área porque a razão principal da pesquisa era registrar a memória da Balaiada, a grande guerra civil que devastou a província entre 1838 e 1841 . Nessa luta de camponeses e vaqueiros livres participaram também milhares de escravos, liderados pelo Zumbi maranhense, o Cosme. ${ }^{8}$ Decidi conversar sobretudo com as pessoas mais idosas nos povoados e bairros rurais, assim como nas sedes dos municípios. Entre elas encontrei muitas que tinham mémorias detalhadas e vivas do passado da família e do seu lugar. Acredito que a falta de luz elétrica na maioria dos povoados nessa época, e a consequente ausência da televisão, ajudou muito na preservação da memória do cativeiro. Seu Simião, o líder comunitário de Bom Sucesso, por exemplo, lembrava oito gerações de seus ancestrais. Entrevistei também pessoas mais jovens, que revelaram conhecer um vasto fundo de memórias apreendidas com algum familiar ou ancião do lugar. Conversei com mais de 600 pessoas em 20 municípios dos 35 que existiam então na região entre a BR São Luís-Teresina ao sul, os rios Itapicuru a oeste, Parnaíba a leste, e o Oceano Atlântico, ao norte. Escolhi trechos de 91 depoimentos para inclusão no texto. ${ }^{9}$

Quem então vai falar do tempo do cativeiro, ou melhor, onde foi possível colher uma memória oral que não fosse a reprodução da visão senhorial? À primeira vista parecia evidente: só os descendentes de escravos podem contar a outra versão. E realmente, em 1982, ainda havia muitos descendentes - filhos ou netos - de cativos, espalhados pelo interior do Maranhão:

"Eu sou de um lugar onde era uma feitoria, Novo Mundo. Só tinha preto nesse lugar. Hoje já se acabou tudo. De mais velho só tem eu e mais alguns."

Maria José Moreira

Codó

Mas estas pessoas nem sempre eram isentas de adotar, por diferentes razões, uma visão que havia sofrido o impacto do ponto de vista senhorial, como, por exemplo, a opinião popular a respeito da Princesa Isabel. Por outro lado, se muitos descendentes de senhores de escravos diziam: “meus avós não

\footnotetext{
${ }^{7}$ Matthias Röhrig Assunção, A Guerra dos Bem-te-vis. A Balaiada na memória oral, São Luís, SIOGE, 1988; 2ª Edição, São Luís, Editora da UFMA, 2008.

${ }^{8}$ Maria Raimunda Araújo, Em busca de Dom Cosme Bento das Chagas - Negro Cosme: Tutore Imperador da Liberdade, Imperatriz, 2008.

${ }^{9}$ Ver a lista dos entrevistados, por município, no anexo de A Guerra dos Bem-te-vis.
} 
judiavam com os seus escravos, tinha outros que judiavam", isto não acontecia sempre (ver, por exemplo, os depoimentos de seu Acácio e de Francisco Rodrigues a seguir).

Além do mais, encontrei várias pessoas que eram descendentes de escravos e de senhores. Conhecem de perto a escravidão, como o Sr. Domingos Raposo Ramos (Timbiras, ver foto). Do lado do pai, o Sr. Domingos é neto de Orvídio Raposo e Alexandrina, uma liberta, filha de escravos de João Raposo (pai de Orvídio). Contava ele que a avó Alexandrina sempre intervinha em favor dos escravos junto à iaiá. O João Raposo era criador de um lugar chamado Curador, no Piaú, "onde não teve escravos". Do lado da mãe, o avô Aniceto Lima de Azevedo era branco, filho de dono de escravatura, um português muito rico chamado João do Macaco, "macaco porque na fazenda tinha muita escravatura". O avô casou com uma "índia", Genoveva. Esse avô, que casou fora da linha, sempre falava como o pai maltratava os negros ("dava pisa nos negros demais") e como os irmãos mais velhos da mãe "eram malvados com os caboclos". Assim sendo, descendente de senhores de escravos, de escravos e de caboclos, o Sr. Domingos diz com razão: "Eu sei da escravidão, eu sei como era malvada".

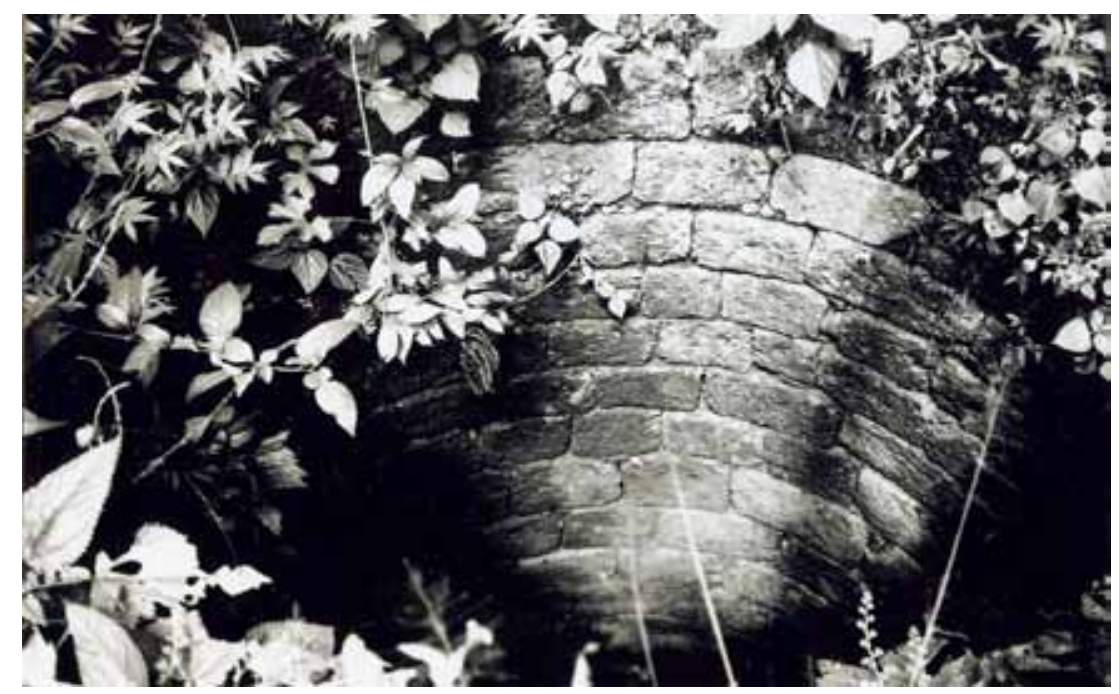

1.São Joaquim (município de Timbiras)

Poços coloniais cavados por escravizados são testemunhas da cultura material do Tempo do Cativeiro. 
Outro grupo de informantes era aquele formado por pessoas que conheceram de perto um preto velho ou uma preta velha do cativeiro (o que foi o caso também de alguns grandes estudiosos da escravidão, como Gilberto Freyre). Ligados a eles por relações de amizade ou parentesco, lembravam as histórias mais contadas por essas testemunhas diretas. Era o caso da Dona Dedé Matos, por exemplo. Em todo caso, impõe-se uma apreciação circunstancial que leve em conta as motivações do informante, todo o seu background. Para dar um exemplo de como a mesma história podia ser contada diferentemente, reproduzo a seguir duas versões de um roubo e seu descobrimento no Paraíso (município de São Bernardo). A primeira foi dada por um descendente da família Pires:

"Negro naquele tempo era bicho safado [sic]. Um negro de São Raimundo roubou um carneiro do Paraíso. Agora ele foi, roubou as botinas de outro negro e foi roubar o carneiro. Então foi descoberto porque o negro feitor conhecia as botinas mas também a passada do que roubou."

Essa versão seria para demonstrar que, não somente os negros do centro próximo a São Raimundo roubavam, mas, que, além disso, eram traiçoeiros com os seus semelhantes, não havendo, assim, solidariedade entre os escravizados. A outra versão já enfatizava a destreza do preto velho em ler passada:

"Tinha um negro que era bom de conhecer rastros de gente e de animal. Um negro roubava coco de noite no Paraíso e enfiava ninho de xexéu nas pernas para o rastro não ser reconhecido. Chamaram o velho e esse disse: 'O rastro não dá para reconhecer, mas a passada é de fulano'. Como ainda tivessem dúvida, mandaram desenterrar um cavalo que tinha morrido alguns anos atrás e marcaram um rastro com o casco dele no lugar dos animais beber. Levaram o velho e esse disse: 'Rapaz, será que animal tem alma? Porque se tem, passou aqui o cavalo de tal que já morreu faz anos”".

Bernardo Coelho Lima

Juá/São Bernardo

A visão do caboclo que não teve envolvimento com o cativeiro era mais distante. É uma apreciação sem aquela emoção que tomava conta, ainda em 1982, daqueles que sofriam por seus avós:

"Escravidão? Era a sujeição para o pessoal pardo. Eu ainda alcancei o pessoal cativo. Não tinha valor. Eram os pardos. Os brancos comprava um casal de preto 
para trabalhar para eles. Traziam da África e aqui vendia num dia e trabalhava pros brancos sem ganhar coisa nenhuma, só a bóia”.

Teixeirinha

Brejo

Como se verá mais adiante, algumas categorias usadas pela memória oral são particularmente relevantes. São eles o "tempo do cativeiro", "judiar" com os escravizados, e a oposição entre o "bom senhor", o "ruim" e o "malvado". De fato, parecem ter sido uma constante na memória oral da escravidão no Brasil. Os depoimentos sobre o tempo do cativeiro foram organizados segundo três temas: o trabalho cativo, a violência que sofria o escravo e sua resistência.

a) TRABALHO

O cativeiro é desde logo associado às casas-grandes e feitorias, cujas ruínas salpicam a paisagem do Maranhão antigo. Sem nenhuma proteção do Patrimônio Histórico, atestam que a consciência histórica da oligarquia sucessora dos antigos senhores não passa de uma visão turística do passado visando o lucro a curto prazo. Limita-se a alguns projetos de manutenção e restauração, situados em áreas privilegiadas do Estado (São Luís e Alcântara). Desta maneira, do "Tamancão" de Ana Jansen às antigas Fortalezas do Itapecuru e do Munim, é iminente o desmoronamento de grande parte do patrimônio histórico estadual, quando isto já não é fato consumado, como aconteceu com todos os sobrados de Rosário e a grande maioria das casas-grandes do Itapecuru, onde se encontram apenas poços aterrados e paredões sepultados nas matas e capoeiras. No Baixo Parnaíba, as três casas-grandes do tempo do cativeiro que encontrei em pé eram: Sucuruju (Brejo), Santa Cruz (Buriti de Inácia Vaz) e Paraíso (São Bernardo). Subsistiam graças aos cuidados solitários de seus proprietários.

A memória oral me parece, nessa altura, mais duradoura que a ambição senhorial, já que muitas feitorias das quais nem traço existia ainda eram lembradas. No Itapecuru, desde a foz (Boavista dos Bayma) até Caxias, a memória oral registrava (como também atestam todos os documentos) grande quantidade de feitorias, fazendo das margens deste rio o principal sustento da economia de exportação. Eram situadas na proximidade imediata do rio ou à beira de um riacho ou igarapé, situação que garantia a comunicação com a capital da Província. Quando se situavam mais para dentro das matas, era 
preciso abrir caminhos que eram praticáveis a carros de boi, somente no verão (como no caso de Flores).

No Munim são atestadas muitas feitorias na região baixa do rio, chegando a Manga (hoje Nina Rodrigues), porém, vão se tornando mais escassas. A memória oral se lembrava de uma série de casas-grandes ao longo do rio Preto (como Mata do Brigadeiro, Guabiraba). Já no rio Iguará, que parece ter sido um foco importante durante a Balaiada, só encontramos ecos de duas fazendas de escravos. No Baixo Parnaíba a memória oral atestava feitorias tanto na margem do rio como na margem de riachos e rios que deságuam no Parnaíba (como o rio Buriti, por exemplo). No litoral, tive notícias de fazendas de escravos no rio Preguiça, no rio Grande (região de Santo Amaro) e uma na Miritiba (hoje Humberto de Campos).

A lembrança popular da distribuição das fazendas faz eco a outras fontes, como os registros de terra de 1854 , que atestam que nas regiões do litoral e nas chapadas entre o Munim e o Parnaíba, as fazendas de escravos eram muito mais raras do que à beira dos rios Itapecuru, Munim e Parnaíba. É verdade que a memória oral talvez só lembre as grandes feitorias e não aquelas que utilizavam reduzida mão de obra escrava, às vezes complementar à mão de obra familiar. As grandes feitorias se concentravam, evidentemente, naqueles lugares que dispunham de boas terras para o plantio de algodão ou açúcar, assim como de vias de acesso para a comercialização. Isso impediu que as terras entre o Munim e o Vale do Parnaíba fossem tão procuradas, já que aí são frequentes as terras muito arenosas e tem poucos rios navegáveis.

A memória oral lembrava os donos das fazendas e os laços de família e solidariedade entre eles.

"Para fazer a rapadura, os senhores se emprestavam os escravos uns pros outros."

Benedito Alves

Vazantinha/Magalhães de Almeida

As fazendas da família Pires, no Baixo Parnaíba, são um exemplo do reino de uma família sobre toda uma área:

"Paraíso era a sede das outras. Era do Comendador Pires Ferreira. João de Deus era o genro do comendador. A lagoa (do Bacuri) cresceu e tomou a casa do Bacuri onde morava o João de Deus Pires Ferreiro, mas o Bacuri não era fazenda. Era estágio pras filhas descansar. No Santo Eugênio e no Santo 
Agostinho também tinha fazenda dos Pires. Era Francisco Florindo de Castro casado com uma da família Pires. O Baixão do Capim era do Tote Pires. $\mathrm{Na}$ Santana tinha outra propriedade. E São Domingos (Buriti dos Lopes) e Tabuleiro eram fazendas dos Pires no Piauí".

Chico Tobias

Magalhães de Almeida

"Por aqui teve casa-grande no Paraíso, era do João de Deus Pires. No Bacuri, era de Antonio Pires. No São João, era a casa-grande velha do João de Deus. Na Santa Maria, também do João de Deus. No Bebedouro de São Pedro: era da Chiquinha Castelo Branco e do pai dela Domingo Pacífico. Na Malhadinha, que era de dois irmãos, Paulino e Analina. No Angico, que era do Domingo Rodrigues. Teve no Santo Inácio e no Retiro".

Bernardo Viriato

São João/Magalhães de Almeida

É aquele mundo "que o português criou", construído à custa do sangue e suor dos cativos. A plantação era assim uma grande empresa agrícola:

"Eu alcancei o vaquejador do José Carlos Frazão. Esse me contou que a casagrande ficava onde hoje é a base. Uma estrada larga e limpa ia até lá por onde caminhava os pretos dele. Ele morava num sobrado, mandava limpar a estrada para olhar da janela do sobrado os pretos dele, e quem não vinha no regulamento dele, ele mandava surrar pelo adomador. Tinha duas filhas; quando uma tinha pena dos pretos, enchia as mãos de prata e jogava no preto e ele achava graça e não mandava surrar. Um centro, a Passagem Franca, era mandado por um preto dele. Ele mandava roçar 100 braças de gergelim, 100 de milho, 100 de arroz, 100 de feijão, 100 de carrapato e 100 de mandioca. De tudo 100 braças, ele não plantava misturado como hoje se planta. Ele tinha 3 parelho de preto, que era dois homens carregando uma taboca e a rede amarrada e duas pretas com chapéu de sol e os 3 parelho revezava, assim que ele andava. Ele tinha pretos nos Centros de Cassó, Passagem Franca, São Joaquim, Boa União. Era homem rico, senhor! Ele tinha 700 e tantos pretos só dele. As pretas nova que ele desejava ele comia e depois dava para outros pretos. Os escravos tinha que trabalhar de graça. Ganhava só uma camisa e uma calça de perna estreitinha e comida. O vaqueiro dele não ganhava uma cria. Era um homem fino, magro".

Mundico Seabra

Humberto de Campos 
"Minha avó contava: De um lado ficava a Igreja que recebia os padres, do outro ficava a morada do José Carlos Frazão, um homem que tinha arrecadado a área da Miritiba. Ele trabalhava com diversos homens na lavoura. Trabalhava nos centros do rio Munim e de lá transportava carga até a Miritiba. Daqui remetia cereais de lavoura para São Luís e, do Munim, farinha e carrapato. Ele tinha diversos depósitos na estrada. Muitos homens trabalhavam para ele."

Caú

Humberto de Campos

Os senhores, como Frazão, aliás, não tinham muitos escrúpulos para aumentar o seu domínio:

"O vaquejador do José Carlos me contou: um vaqueiro do José Carlos Frazão achou uma população de preto. Aí o Frazão inventou que ele tinha ido onde o rei, pediu como homem pobre que lhe desse aqueles pretos para ele. Ele era danado! Inventou que o rei D. Pedro II deu uma carta para ele ler pros pretos que eles tinham que lhe obedecer como senhor e quem não obedecia o rei mandava enforcar. Fez de conta que tava lendo esta pros pretos. Aí os pretos se ajoelharam e tomaram benção a ele. O senhor não calcula como é a gireza dele! Era no Cassó (hoje município de Primeira Cruz)”.

Mundico Seabra

Humberto de Campos

A memória oral lembrava trabalhos executados pelos cativos, porque só mesmo escravo para executar tais tarefas. São rampas, poços, paredões e cercas de pedra (ver foto):

"No Olho d'Água ainda tem os paredão da casa-grande. O Bebé Rodrigues mandou fazer uma cerca de pedra pelos negros. Essa cerca de pedra era da altura de uma braça caveira, hoje já tá mais baixo".

José Vicente

Canto d'Água/Santa Quitéria

“A Santa Maria era feitoria do João Paulo Miranda, morador do Brejo. (...) Trabalhava com cana. Mudou o rio com uma encanação para moer a cana. Aquele engenho ficou bonito. Morreu com desgosto porque o rio secou, aí o engenho não correu."

Maria Alves da Silva

Porto Velho/Urbano Santos 


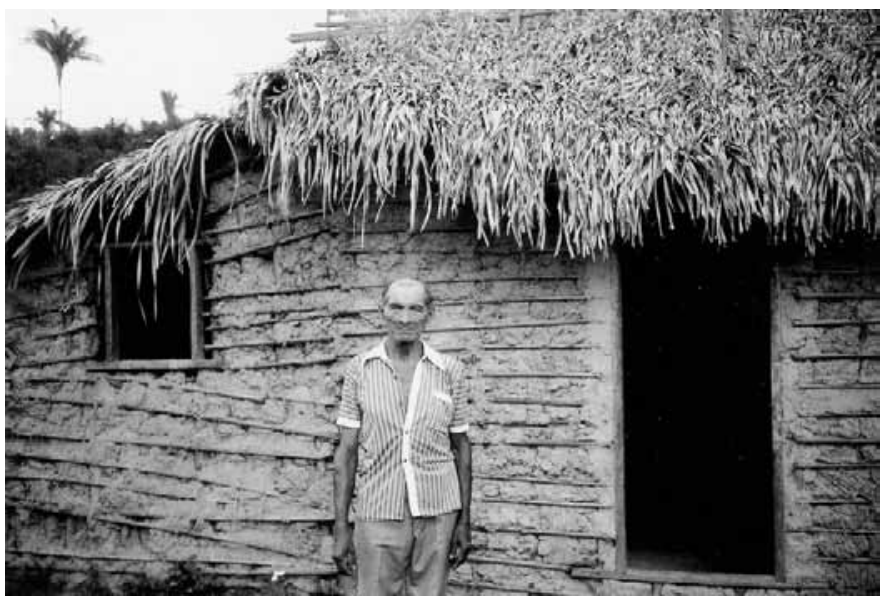

2. Timbiras (sede)

Os antepassados de seu Domingos Raposo Ramos são escravos, senhores, caboclos e forros.

"Paraíso, Bacuri e Santa Maria era do mesmo feitio, feito por escravos. Na Santa Maria tinha seis furquilha de cumieira ${ }^{10} \mathrm{e}$ cinco varandado: dois de frente e três nos fundos. Tinha peitoril largo que duas pessoas podia deitar."

Bernardo Viriato

São João/Magalhães de Almeida

Neste cenário, a fartura da casa-grande sempre era lembrada:

"Um dia sim e outro não, matava uma rês no Paraíso."

Chico Tobias

Magalhães de Almeida

"De Mandioca alcancei a Tomazinha, a Anajazinha, a Vermelhinha e a Carregadeira. Tinha uma mandioca como a Anajazinha que era um pau brabo, uma raizona dessa grossura... quando arrancava era dois, três homens para suspender o pé da mandioca. Isso no Santo Agostinho, no baixão do Juá, mas hoje tá tudo acabado... Mês de farinhada era doze cargas de burro todo dia. $\mathrm{Na}$ casa da farinha tinha uma bulandeira com quatro burros puxando, tinha

${ }^{10}$ Forquilha que sustenta o telhado. 
oito para esse serviço. Deitava às dez da noite e se levantava na primeira hora da madrugada para lavar a goma, os coxo de goma, aqueles pauzão de goma."

Raquel

Férias/Magalhães de Almeida

A escravidão foi introduzida "para o sustento da lavoura". Ser escravo do eito foi sem dúvida a condição mais comum do ser escravo. Mas, instituída para a plantação, a escravidão acabou permeando toda a sociedade e assim foram aparecendo formas secundárias da escravidão.

Na plantação mesmo, teve a segmentação entre escravos do eito e escravos que trabalham na casa-grande, esses relativamente mais favorecidos. Outra ocupação importante na plantação era o vaqueiro. São encontradas, na memória oral, referências tanto ao trabalho cativo, como ao trabalho livre com o gado:

"Me criei na Santa Maria. Meu pai foi vaqueiro 40 anos, ele chamava Viriato Francisco da Cunha. Meu avô morreu com 96 anos. Ele era piauizeiro, veio ser vaqueiro na fazenda de Santo Agostinho. Lá ele ficou 16 anos de vaqueiro. Não quis mais e comprou essa terra aqui. O patrão dele repartia as cria: de quatro, um. De todo animal."

Bernardo Viriato

São João/Magalhães de Almeida

O trabalho de Raimundo Gomes, um dos grandes líderes da Balaiada, levava os estigmas da escravidão, razão pela qual, quando era exercido por livres, estes eram muitas vezes "pardos" (descendentes de negro com mulato no Maranhão oitocentista) - como Raimundo Gomes - ou cafuzos. Trabalho com gado requeria muita coragem, como se vê pelo depoimento seguinte:

"Nasci no Santo Agostinho. Era do velho Castro Pires. O cativeiro eu não alcancei. Já era o meu pai que contava. Ele foi escravo no Santo Agostinho, Antônio Augusto dos Santos. Papai contava quando era o finado João de Deus, que era um malvadão do tempo do cativeiro... Papai era vaqueiro e morava mais esse senhor dele, Francisco Florindo de Castro. Morava nas Cajazeiras de baixo ou se era nas Cajazeiras de cima... Agora veio ele sozinho, mandaram ele sozinho de noite escura chamar o 'Satanás' aqui no... ([A filha interrompe:]'Não é Satanás, diga o nome, mamãe') 'Satanás', porque era malvado... Aqui, como era o nome, que ele morava? Mas ele sabia a mão direita dele. Ele via onça roncar para cá, via onça para lá, via onça roncar para acolá e ele no caminhozinho. 
Quando foi bem cedo que ele chegou e deu [o] velho João de Deus vinha, que ele veio o caminho tava triado de rastro de onça que ele só [ou]viu o ronco".

Raquel

Férias/Magalhães de Almeida

Parece ter havido, também, escravos exercendo ofícios mecânicos.

"Meu avô Brás era escravo e pedreiro, participou do serviço da Igreja de Rosário. Ele podia trabalhar onde queria, mas tinha que entregar o salário todo pro Senhor. Esse então lhe dava uma parte. Ele morreu forro.”

Dudu

Rosário

A respeito de uma escravidão doméstica, tipo de escravidão que era frequente em muitas sociedades africanas, encontraram-se algumas referências indicativas desse tipo de cativeiro, o que nos leva a considerar a hipótese de ter havido uma camada do campesinato mais abastecida que, sem poder pretender ser dona de plantação, era intimamente comprometida com o sistema escravista do qual também lucrava. Isto, aliás, sempre foi do interesse dos grandes proprietários escravistas porque aumentava a base social interessada na manutenção da escravidão.

"O meu bisavô e o meu avô tinham escravatura. O meu bisavô não judiava, os escravos comia na mesa com ele, os filhos dele trabalhava na roça junto com eles."

Pechincha

São Francisco/Anapurus

"Minha mãe era filha de escravo: Pio e Maria Valéria eram os avós. Ela foi criada na escravidão. Quando gritaram a alforria dos negros minha mãe tava com 12 anos de nascida. Meus avós não foram judiados porque foram criados por uma velha que deu tudo para eles, e cada um dos 8 filhos que criou: aviamento, caititu, forno, gado e criação, até um cachorro ela deu. Não lembro o nome dela, só se conhecia ela por 'Iaiá Véia'. Ela era como uma mãe para eles."

Raimunda Pio

Fazendinha/Santa Quitéria 
A memória oral guardou alguns casos que permitem reconstituir a vida cotidiana na plantação. Se um dia sim, outro não se matava uma rês no Paraíso, dificilmente algum pedaço desta carne ia parar dentro do bucho do escravo.

"Comida de escravo era feijão com milho."

Mimi

São Bernardo

"Os negros escravos, de primeiro, comia é milho. Os brancos que botava para eles."

Januária

Almas/Brejo

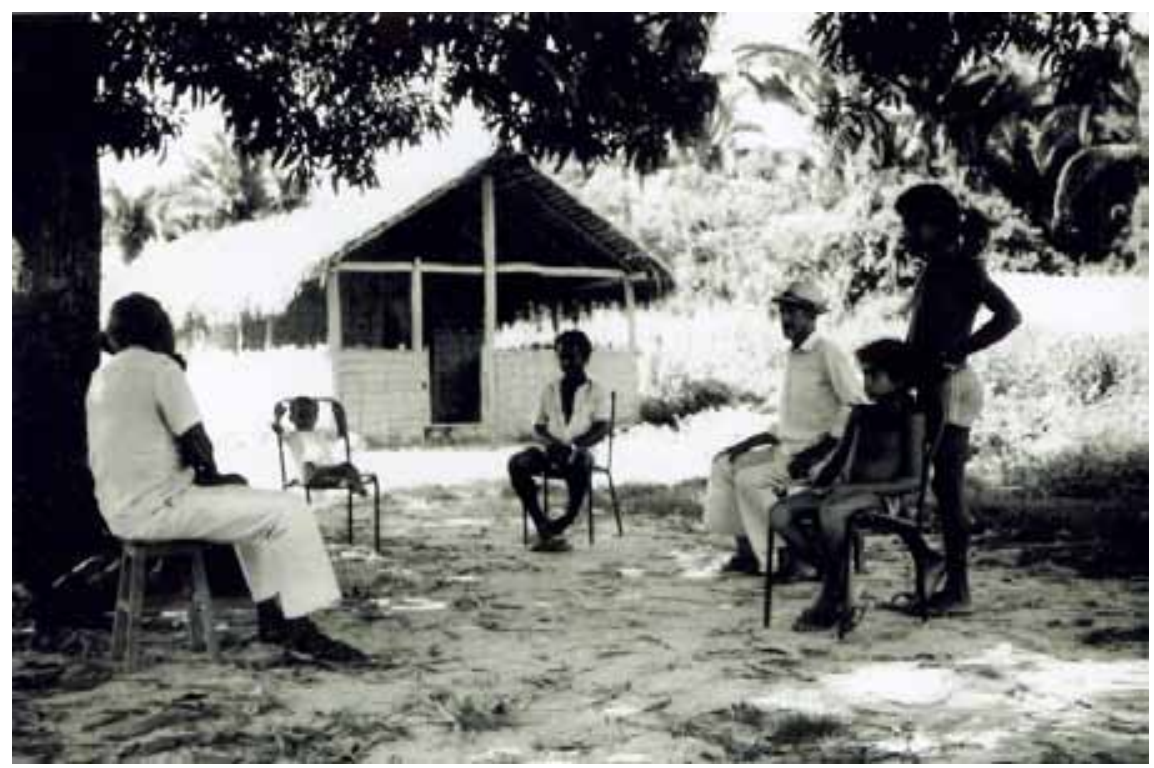

3. Flores (Timbiras)

Três gerações, na sombra: A conversa sobre os tempos antigos.

"Paçoca de gergelim era o comer dos escravos."

Francisca Rodrigues

Currais/São Bernardo 
"Um negro no Paraíso foi reclamar com a cozinheira no meio-dia 'esse feijão não tem azeite'. Aí a cozinheira foi dizer pro patrão que o negro velho tava reclamando que não tinha azeite. Aí esse mandou o preto voltar pro serviço sem almoçar. Chegou de noite, aí a cozinheira foi botar feijão para ele, só cozido na água e sal. Disse: 'Negro Velho, esse feijão não leva azeite', aí o negro velho já morto de fome: 'Não tou mais procurando por zête!' E comeu.”

Benedito Alves

Vazantinha/Magalhães de Almeida

Os costumes eram severos para não permitir que, nessa convivência cotidiana do escravo com o senhor, longe dos centros urbanos, o escravo esquecesse que ele "não tinha valor".

A humilhação do escravo, além de satisfazer o ego do senhor, permitia a reafirmação cotidiana da hierarquia social que o cativeiro instaurou.

“O Negro tinha que dizer: 'Louvado seja Nosso Senhor Jesus Cristo' e abraçava os joelhos pedindo a benção: 'A benção Iaiá' e essa respondia: 'Para sempre seja louvado'. Lá nas onze horas sempre encostava muita gente na casa-grande. Tanto que as cozinheiras às vezes não comia certo com o Louvado Seja, porque tinham que dar pratos para os que deram o Louvado Seja, e por isso diziam: 'Vamos almoçar, logo, antes do Louvado Seja..'

Mimi

São Bernardo

"Esse Florindo, papai me disse, que eles não... que não era da parte deles (dos vaqueiros), mas os escravos quando levantavam, ele vinha lá de dentro pisando, Ho! Ho! temperando a goela... Os negro tava tudo acolá, tava coalhando de medo e tinha que esperar que ele botava a cabeça e eles diziam, não tinha a benção: 'Louvado seja Nosso Senhor Jesus Cristo!' E ele respondia d'acolá: 'Para sempre seja Louvado...' Aquele que não dissesse, apanhava...'

Raquel

Férias/Magalhães de Almeida

"No cativeiro cada um tinha o seu serviço."

Raimunda Pio

Fazendinha/Santa Quitéria

Mas para todos era de noite e de dia: 
"O trabalho do escravo chamava tarefa, de dia, e serão, de noite. Serão era socar arroz ou milho ou bater arroz ou milho".

Domingos Raposo

Timbiras

"Os escravos sofriam muito. Eles apanhavam muito. Os escravos de Raimundo Munim de noite socavam o arroz e iam dormir muito tarde."

Tomásia Lages

Codó

"Os negros do Paraíso, quando voltavam de tarde das roças pra diante do São Raimundo, quando passavam aqui, carregavam mandioca que eles tinham que descascar para fazer farinha ainda de noite pra trabalhar no outro dia. Tinha um lugar chamado 'Rancho dos Negros' onde eles descansavam na hora do almoço, do sol quente. A farinhada era feita pelos negros e cada um levava um jacá (cesto feito de talo de mandioca) quadrado no ombro e jogava na casa da bulandeira (motor de pau puxado por um cavalo pra mover o caititu). As negras descascavam de noite e no outro dia já tava a massa torrada por eles."

Agápio

São Raimundo/São Bernardo

"Negro de noite tava de algodão fiando e de dia na roça. Taca! Diz que negro pegava taca como quê! Negro padeceu. Apanhava sem necessidade."

Avelino Gonçalves

Pereira/Mata Roma

"Minha avó era da Mata, município do Brejo. Ela foi escrava e diz que sofreu muito. Só tinha uma filha do tempo da escravidão, banhava ela mais o filho da Sinhá. Paulino Diniz era o dono dos escravos. Ela torrava, pisava e cozia o coco e tirava uma quarta de azeite todo santo dia."

Maria de Lourdes da Conceição

Carmo/Mata Roma

"As roupas dos senhores eram lavadas de dia, as dos escravos de noite."

Dedé Matos

Rosário 
"Minha avó, Bertolina, era escrava e morreu escrava. A feitoria era na Prata, do Henrique Rocha. Tinha olaria, saboaria (de andiroba) e engenho. Os pretos moravam lá e ía e pros canaviais que eram por lá, também. As pretas tinham as cabeças amarradas, para pudê ajuntar e botar no carro de boi a cana que os homens cortavam. Aí levava pro engenho."

Dudu

Rosário

As mulheres, além do trabalho da roça, tinham tarefas domésticas extenuantes como fiar algodão e fazer renda.

"No Paraíso tinha só 15 dias de resguardo. As escravas levavam o neguinho numa tipóia para a roça e voltava a criança de cara inchada de mordida de muriçoca."

Mimi

São Bernardo

"Nós fiamo algodão. Minha mãe era trabalhadeira, graças a Deus, como a filha dela. Ela no meio do terreiro, fiando na luz, fazendo corda, era fazedor de corda para rede. Não tinha esse negócio de cama não."

Raquel

Férias/Magalhães de Almeida

"Se fazia renda. Era um monte de menina sentada na varanda. Tinha tarefa: fazer um tanto de renda. Muitas vezes elas não comiam, olhava o prato e não podia comer para não perder tempo. A renda era só para a família dos senhores."

Mimi

São Bernardo

Perdurou este trabalho de renda por tarefa além da abolição. O depoimento de Dona Raquel, já livre, apanhando da iaiá, atesta que as datas históricas nem sempre operam cortes absolutos nas relações de trabalho:

"Era uma meia quarta de renda para fazer por dia. Para uma pessoa render, quem sabia mexer com bilro fazia só uma meia quarta por dia. Se acabasse de dia, era de dia, e se não acabasse acabava de noite. Acho que é por isso que minha vista tá ruim. Todo santo dia era meia quarta de renda, todo santo dia... (seis dias) da semana, nem que acabasse de noite: era tarefa! Por isso que o povo do outro tempo era trabalhador, hoje as moças são preguiças. Não sei nessas outras terras porque nunca corri terra, mas aqui, na beira dessa lagoa... 
Para fazer aquela renda bem larga de 2 palmo para fazer vestido, tirava no papelão. Renda de 2,5 de 6 dúzias de bilro. Eu mexia com duas dúzias numa almofadona dum saco deste tamanho, desta largura [mostra]. Cheio daquele papelão com dois, três dúzia de bilro, eu mexi. Pelejei tanto [...] O povo era trabalhador nesse tempo. Eu não alcancei o cativeiro não, mas trabalhava de tarefa. Aí tem muita colega... uma morreu outro dia, mãe desse meu genro aqui, morreu ceguinha. E esta velha que morreu, Ave Maria! gritava: 'Me acude, minha gente! Minha cabeça quer rachar'. Os olhos dela aquele poço de sangue... As senhoras, aquelas danadas! A gente apanhava... Dava de palmatória. Mas a gente quebrava os bilro, não fazia renda, quebrava os bilro. Mas graças a Deus não tenho as mãos aleijadas. Sou limpa graça a Deus."

Raquel

Férias/Magalhães de Almeida

Além desses trabalhos produtivos, havia que satisfazer as extravagâncias dos senhores, que, ociosos, tinham que procurar alguma distração ou, mais uma vez, exibir o seu poder:

"Na Ilha Velha tinha um casarão. Só atravessava o braço do rio, que ali é estreito, com a maré seca. Todos os escravos se deitavam para o Senhor passar por cima e chegar até o Rosário".

Dedé Matos

Rosário

"No tempo da escravidão era muito o sofrimento. Tinha dona rica que só dormia embalada por uma escrava. Tinha que embalar até ela dormir."

Janu Santana

Chapadinha

Os senhores gozavam de um privilégio que, nos dias de hoje, só se concede aos mortos e moribundos:

"Dois negros levava o branco na rede como se fosse um doente".

José Leal Lélis

Flores/Timbiras

b) VIOLÊNCIA 
A superexploração do trabalho escravo, que tinha como único limite a resistência física do cativo, só era realizável através da coerção. É o que poderia se chamar de violência cotidiana do tempo do cativeiro. Ela é a ameaça constante de taca para a tarefa não cumprida, para qualquer "falta" cometida no trabalho. Fazia parte do pão cotidiano do escravo:

"Os escravos sofria muito. Trabalhava por tarefa e tinha que dar aquela quantia de arroz, de algodão, senão ia pra taca. Taca ou reios, era um pedaço de pau com couro".

José Leal Lélis

Flores/Timbiras

"Os negros tá tudo trabalhando, capinando. Pra fazer trabalhar mais depressa um osso de bode na ponta do reio da taca: chamavam 'mocotó de bode'. Quando dava lapada com essa taca o negro que tava cochilando de tanto trabalhar porque o coitado trabalhava muito - acordava. Os negros tinha tudo calo de tanto trabalhar e apanhava."

Domingos Raposo

Timbiras

"Se o escravo não executou a tarefa, aí que ele ia sofrer. Porque ia cortado os quarto, ia pregada a orelha no banco, ia apanhando de reio que largava o couro, reião grosso de boi, cortado de boi, seu moço, dado pela mão de homem, como queimadura de fogo... assim que ficava quando dava de reio, pegava eles, botava no pé de pau, metia o reio."

Raquel

Férias/Magalhães de Almeida

"Meu pai, Antônio Rodrigues de Pinho, me contava que o meu avô, Porfírio de Pinho, tinha uma fazenda de escravos na Santa Isabel (hoje município de Presidente Juscelino). Não alcancei meu avô, mas meu pai disse que era muito mau com ele. A mesma tarefa que ele dava pros escravos meu pai tinha que fazer também. O velho botava os pretos para trabalhar, aí chegava na roça e, se os pretos não estivessem fedendo (de suor), ele dava uma tacada em cada preto. $\mathrm{Na}$ alforria foram todos embora. Acho que só meu avô que teve escravos nessa região (Cachoeira de Morros).”

Acácio

Cachoeira de Morros/Morros 
Ninguém escapava e nenhuma desculpa era válida:

"Uma preta velha me contou de quanto os senhores eram maus. Contava de uma feitoria no Veado Branco (município de Brejo), aí tinha um preto velho com os pés grande demais e não podia andar bem. O patrão que levantava tarde depois do frio, tomava banho, tomava café, pegava o cavalo para ir à roça ver os preto trabalhar e ainda alcançava ele no caminho. Aí surrava ele: 'Caminha! negro velho!' Ele: 'Não posso, senhor!' porque não podia. Mas o senhor surrava e depois cortava as nádegas e botava sal".

Maria Garreto

Mata Roma

"Conheci pretos velhos depois de liberto. Ouvia contar que o feitor obrigava a trabalhar até doente, tinha um que chegou a morrer em cima do cabo da

4. Arará (Vargem Grande) Dona Firmina Rosa nasceu no mês em que seu pai foi alforriado: maio de 1888 .

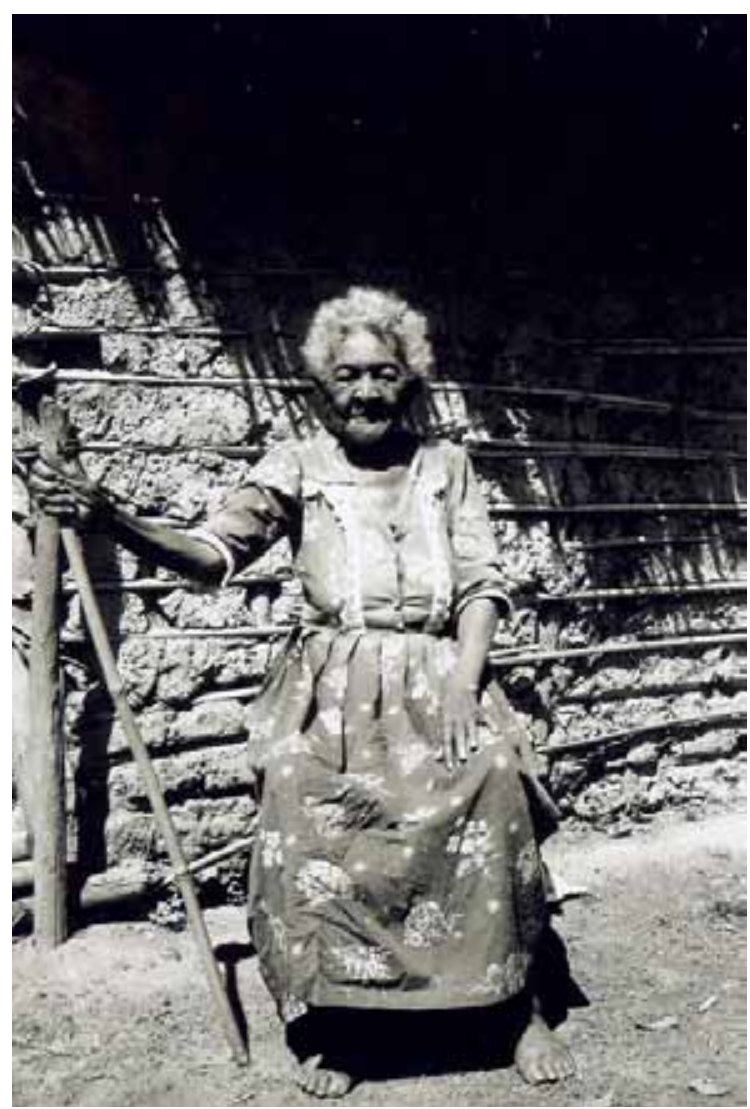


enxada. Os outros olhava para ele com olhar de piedade e não podia dizer nada, e o feitor gritava: 'Vamo! Vamo!'”

Isaac Francisco Montelles

Anapurus

Em geral, o senhor não ia sujar as mãos. Deixava que a escravidão pervertesse até as relações de família:

"No tempo do cativeiro, tinha dia que o escravo não comia, era só apanhando. Meu pai contava que ele passou muito mal. Trabalhava de roça e de canavial no Cabogé, Bacabal, que ficavam perto um do outro e morava aqui perto. $\mathrm{O}$ avô da parte de pai era Damião de Souza, também escravo dos Garreto. Ele era feitor. Era ele que batia no meu pai”.

Firmina Rosa de Souza

Arará/Vargem Grande

Assim o negro trazia no seu corpo as marcas da violência cotidiana. Ferrado que nem gado, cicatrizes dos "estímulos ao trabalho" e orelhas dependuradas de pregar no banco ou de tanto puxar:

"A velha Brígida, do Santo Agostinho, enlouqueceu na Alforria. Ficou doida porque ela não tinha mais de quem puxar orelha, que os negro dela tinha tudo a orelha como jumento dependurada de puxar. Só chamavam ela de Dona, Dona, Dona. Era mulherão gorda, malvada como quê!"

Raquel

Férias/Magalhães de Almeida

Além desta violência cotidiana, havia a violência mais requintada da punição exemplar. A história de negros que tiveram as costas retalhadas com navalha depois de açoitados e o "curativo" de sal e pimenta nessas feridas, era a mais frequente lembrada pela memória oral a respeito do Cativeiro. Ouvi-a inúmeras vezes em muitos municípios, tendo como protagonistas os escravos e senhores locais:

"Joaquim Antônio, um grande de São Bernardo, era muito rico, mas muito ignorante e era ruim com os negros. Quando era para punir um, ele mandava dois negros surrar com uma chibata que tinha na ponta um osso de bode. Depois, nos lugares onde ficava inflamado, ele mandava cortar com navalha 


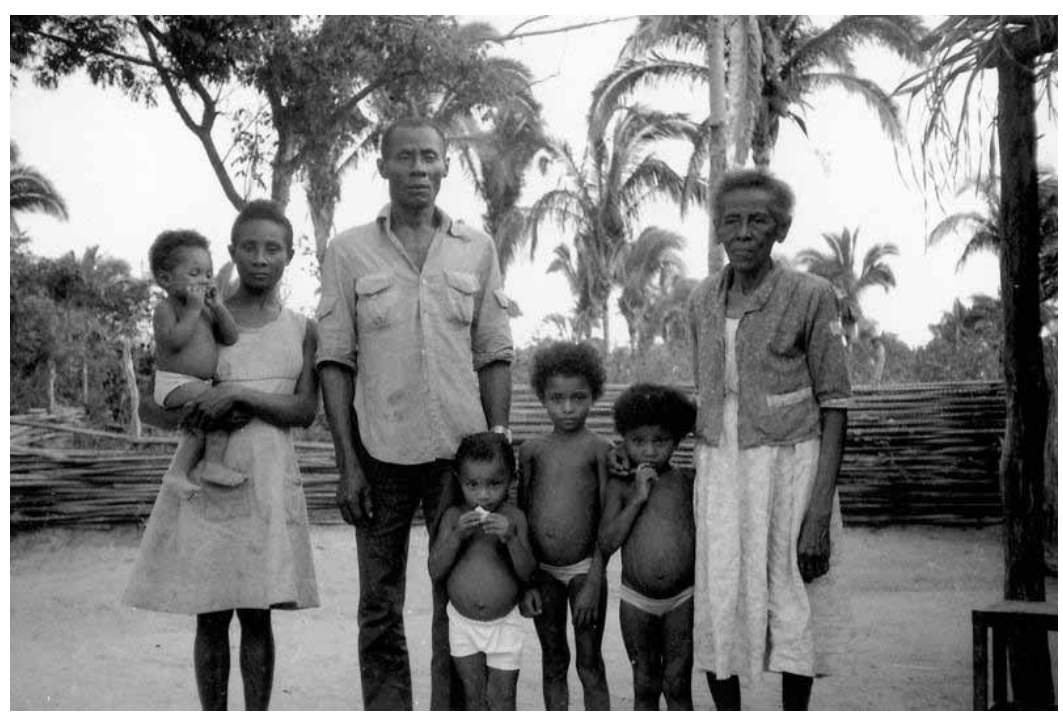

5. Almas (Brejo)

Dona Januária e seus filhos e netos. A memória da luta do campesinato desde os tempos heroicos da Balaiada.

para sair o sangue. Dizia ele que era para não apodrecer. Aí preparava uma gororoba (remédio preparado) que continha pimenta, esterco de gente misturado com égua, sal e mastruz. Ele era malvado e botava os pobrezinhos para tomar aquilo".

Janu Santana

Chapadinha

A punição podia surgir a partir das "faltas" no trabalho cotidiano, já que quase nada, nem ninguém, podia pôr limites ao escravocrata enfurecido dentro de sua propriedade:

"A Gregória Marques, antiga escrava e madrinha da minha filha, me contava muitas histórias: os Rocha, família grande, eram donos da Prata (Rosário). Um dia, Juca Rocha foi para a roça e sentiu falta de uma escrava, chamou o feitor e perguntou por Joana: 'Ela não veio, dormiu com dor de dente'. Aí ele voltou para a fazenda, lá tinha um casarão. Chamou a preta, pegou um alicate e arrancou todos os dentes da escrava para ela nunca mais faltar serviço por dor de dente".

Dedé Matos

Rosário 
"Minha tia contava: as patroa fazia judiação. Botava elas para fazer renda de frente para parede para não olhar pra ninguém. Aquela que tava olhando ia morrer e morria mesmo, não tinha quem acudisse. A patroa com malvadeza, retalhava ela, salgava, botava amarrada no mourão no sol quente, ou no formigueiro para fazer judiação."

Rosinha

Ribamar

"Meu pai morava aqui nas terras de Santa Cruz depois de casado. Antes morava na Faveira, residência do Hortêncio, cativo, e depois agregado do Hortêncio. Ele trabalhava todo dia da semana para o senhor e foi liberto pela Princesa Isabel. Ele era do Maranhão, minha mãe, cativa também, era do Piauí, aonde eu nasci, município de União aonde fiquei até 10 anos. Tinha turmas de escravos na Faveira, no Sucuruju, na Santa Cruz, na Barra. Quando um senhor criava raiva de um escravo vendia para outro senhor ou judiava com ele. O velho Freita, no Sucuruju, era cego. Ele tinha um escravo com nome Calistre. Estavam na roça trabalhando, aí o Calistre adoeceu com um dor de barriga. Entonces os outros disseram para ele vir para casa, que tava doente e não podia trabalhar. Ele disse que não vinha porque o senhor não ia se dar com aquilo, ia dizer que era preguiça. Acabou saindo da roça e vem para casa para tomar remédio. Quando chegou no Riacho das Barroca Funda, ouviu o tropelo do animal do senhor, que tava, não sei se tava, atrás do serviço dele, ou para alguma viagem. Aí entrou pelo mato, lá deitou-se. Quando o velho Freita chegou bem aonde tava o Calistre parou o animal. Parece que ele tinha um faro. Talvez ele sentiu pelo cheiro do suor e aí chamou ele pelo nome: 'Calistre!' Nas três chamadas Calistre falou. Aí chamou ele para que viesse aonde ele. Então Calistre chegou e ele mandou que se deitasse. Deitou, e ele avançou no Calistre de espora, Calistre ficou foi mais doente. Não morreu naquela hora, ainda contou tudo para os outros."

Zeca Lotide

Macambira/Buriti

"A minha avó dançou no dia da libertação e amanheceu parindo a minha mãe. Minha mãe contou que minha avó dizia que no Paraíso, onde ela foi escrava, se deu o seguinte: Tavam uns escravos fazendo rapadura na fornalha do Paraíso. Um escravo tava mexendo no tacho de mel. Aí chamaram ele para almoçar e aí ficou uma mocinha mexendo o tacho de cobre. Já tava fervendo e a sustância dela não deu (tem que mexer ligeiro) e aí derramou. E ela gritando que o mel tava derramando. Aí o patrão chegou zangado e derramou o mel quente na cabeça dela até quando matou. Ela morreu queimada." 


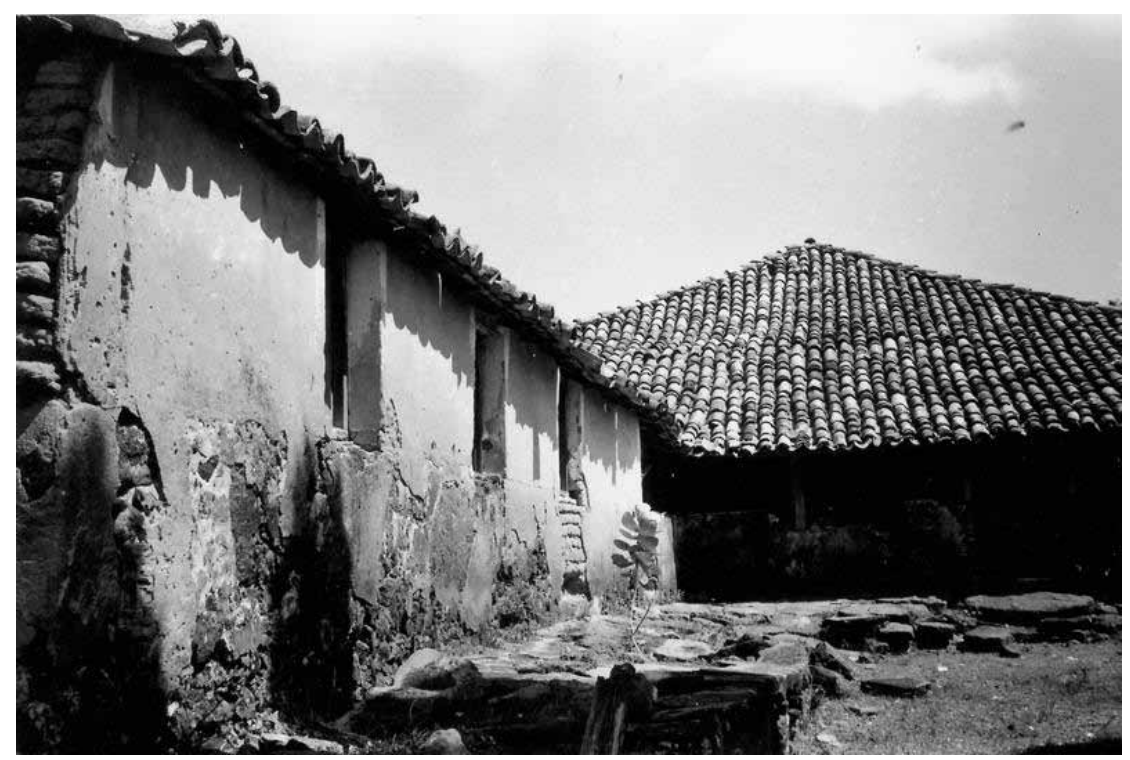

5. Paraíso (São Bernardo)

"Tempo de Malvadeza" I: Moradia de João de Deus. Essa casa-grande continua em pé graças ao cuidado de seu atual dono.

Benedito Alves

Vazantinha/Magalhães de Almeida

A fuga, como ameaçava diretamente a viabilidade do sistema escravista, era punida de maneira exemplar:

"Minha mãe contava tudinho: De muitos lugar fugia, eles ia atrás. Eles passava mão (amarrava) no rabo dos animais e trazia, e quando chegava a taca caía".

Raimunda Pio

Fazendinha/Santa Quitéria

"Minha avó era uma fujona. Ela contava que fugia, mas aí era pior: ia pro tronco, botavam ela pra trabalhar com corrente."

Maria de Lourdes Conceição de Carmo

Carmo/Mata Roma

"Me contaram que no Piauí uma negra fugia muito pra mato. Mandavam um negro em cima de burro atrás dela que levava um chifre de gado que ele amarrava na negra, (depois de ter pegado ela). Amarrava ela com uma corda 
no rabo da burra e aí corria com a negra atrás. E o chifrão grande batendo para dizer que era chocalho. Também no Piauí teve um que matou um negro e mandou cortar ele, tirar os quartos de carne e pendurar todinho que nem gado. Um outro pregava orelha de negro fugido na parede da casa dele que era um sobrado."

Janu Santana

Chapadinha

"Triste aquele que era pegado fugindo. Tinha um alçapão (buraco fundo com caco de vidro). Jogavam o escravo ali dentro e não saía mais. Na Prata tinha um. Só mesmo o feitor que sabia se tinha escravo dentro, porque se botava uma tampa por cima."

Dedé Matos

Rosário

"Sumidores" são registrados pela memória oral em vários lugares:

"Mas nesse tempo o povo era brabo. Tinha muitos senhores maus. Na Água Branca tinha até um poço de jogar escravo dentro. Eles (os donos de escravos) tinham um vaqueiro para ir atrás dos escravos que fugiam".

Pechincha

São Francisco/Anapurus

"Uma escrava custou a tirar o urinol da alcova da senhora. Quando daqui a pouco ela chegou, ela fez a escrava comer o conteúdo todinho."

Raimundo Erre

São Benedito

"Quando dava de safado matava retalhando vivo. Amarrava o negro em banco de aroeiro duro, talhava as costas com navalha, botava sal e pimenta do reino. Quando morriam, eles penduravam que nem gado pelo pescoço num pau. Aí apodrecia e caía aos pedacinhos. Urubu não comia porque tinha sal. Quando dava uma chuva aparecia o cheiro de pimenta do reino com alho, aí sabiam que tinham matado um negro. Eu vi muito poço de sumidor. Na Boa Esperança tinha um. Poço de boca larga e fundo estreitinho de pedra e cal com lâminas de gilete $[s i c]$ no fundo. Aí jogavam eles."

Domingos Raposo

Timbiras 
Os requintes de sadismo de alguns senhores eram lembrados pela memória oral com todos os detalhes:

"Tinha uns senhores ruim que furava o negro com uma agulha para ver se era morto mesmo. Na Lagoa do Cantanhede (hoje Lagoa do Cazuzo) tinha Cândido Cantanhede, dono de escravo. Era mal. Era desse que botava escapa (de armar rede), duas velhas me contaram isso, amarrava com sola as mãos e dependurava na escapa, só com as pontas dos dedos no chão. Ele dizia: 'Sururuca! Sururuca!' e cutucava os maribondo que ia em cima dos negros que ficavam sapateando. Aí as mulheres tiveram que acudir: 'Não mata! Não mata!' para salvar eles. Quando enterraram ele, num caixão bom, chegaram dois cabras desconhecidos e levaram o caixão. E nunca mais apareceu (o corpo) em lugar nenhum".

José Leal Lélis

Flores/Timbiras

"Um negro velho que tinha os pés dele rachado que se passasse o calcanhar assim numa pessoa cortava como faca. Aquele couro secava, aquela rachadura dos pés. Ele nunca calçava. Esse meu padrinho Angirico, ele era malvado. Ele tinha uma negra velha que chamava Cabeça de Onça. A negra velha apanhava! Diz que um dia ela pegou uma pisa tão medonha que diz que rinchou como um animal. Não chorava mais, fazia era rinchar. Só da taca que era demais. Ele fazia um cigarro, naquele tempo ninguém usava cigarro feito, era cortado, e tinha uma negona grande que era quase da altura dessa porta. Ele mandava que ela se sentasse e ficasse assim rebaixadinha, e ele sentava em cima dela assim e cortando aquele cigarro bem devagarinho, para demorar muito. Fazia aquele cigarro com toda demora e, acabado, ele ia fumar e quando tava terminando de fumar que ele saía e ela ali sofrendo o monstro de homem, que o bucho dele era assim (mostra). Sentado nas costas dela e ela gritava: 'Ah! meu senhor! Não agüento mais!' e ele assentado. Era meu padrinho de batismo aquele que fazia essa malvadeza."

Francisco Rodrigues

Currais/São Bernardo

Parece que era uma maneira do senhor matar o tempo e exercer sua "imaginação". Aparece nesses depoimentos todo o lado patológico da relação senhor/escravo, esse último podendo ser levado à loucura:

"Essa senhora criava essa nêga. Quando era de manhã mandava ela pra fonte buscar água. Dizia: 'Vai pra fonte buscar água e tu vem já!' E se a nega cus- 
tasse, quando chegava, ela botava a nêga pra correr de uma parede a outra, até quando cansava que não podia mais nem falar. Aí ela botava de joelho em dois caroço de milho e ficava sem comer e sem beber até meio dia quando o senhor chegasse e mandasse dar um prato de comer para a nêga. Desse jeito a pobre nêga vivia, só faltava ficar doida! Deu graças a Deus quando deram a libertação aos escravos. Aí ela nunca mais quis ser escrava de ninguém. Que ela ainda tinha a fala cansada só de correr. O nome dela era Benedita Virício, e o nome da patroa era Candinha Carvalho da Silva. Minha mãe conhecia todas as duas: uma era comadre da filha dela e a outra era madrinha de casamento, lá em casa”.

Raimunda Santana da Silva

Vazantinha/Magalhães de Almeida

Um capítulo particularmente odiável é o da violência contra a mulher escrava, fazendo do tempo do cativeiro o tempo do estupro institucionalizado:

"No tempo do cativeiro os filhos dos fazendeiros chegava na casa dos cativos e levava as filhas para fazer o que não prestava: sem-vergonhices, os pais não diziam nada com medo de morrer".

Raimunda Pio

Fazendinha/Santa Quitéria

"O meu avô, pai do meu pai, era sem-vergonha mesmo, igualmente eu. Ele botou um paiol na roça dele, na feitoria dele, que era um quarto reservado só para ele. 'Vou olhar os pretos', dizia pra Sinhá branca. Agora tinha uma preta velha, eu alcancei ela ainda, que ele mandava ela deixar bóia para dois nesse quarto. A minha avó Anastácia era escrava e rapariga dele...”

Lázaro

Cachoeirinha/Nina Rodrigues

"Como chamava aquele, que era malvado? É, o finado João de Deus botava as nêgas para dançar para eles poder se pôr acolá, mangando, as negonas gorda dando marrada nos homens com os quartos... Papai era cantador. As moças, no tempo do cativeiro, tinham que dormir com os filhos do senhor. De noite elas tinham que se preparar e ir pros quartos dos rapazes filhos dos senhores. Você pensa que eu gosto de falar? Eu não gosto, Ave Maria! Era muita malvadeza... Se fosse viva eu morria! Tudo papai contava que se fazia de mal. 'Eu não quero ir não, mamãe, Ai! Eu não vou, não, não vou'. Aí quando chegava para dormir nos quartos com os malvados... Pois bem, os pais era ricos e malvados como o finado João de Deus e não queriam que eles fossem procurar a vida 
por fora, não queriam não, ainda hoje tem dela doente. Na dormida, o senhor tá entendendo? para dormir mais elas. Ora! Meu Deus! Nossa senhora! As mães ficavam chorando e elas saíam chorando, Ave Maria! eu não gosto nem de falar, eu lhe garanto que é um bocado ruim, a gente fazer as coisas obrigado, não presta não. Como hoje. Hoje fica uma moça, quando dá fé, os pai tá com ela grávida, aí dentro de casa é um barulho medonho, anda de justiça ... Tem muitos que casam à força. Larga a mulher, foge, vai embora, deixa aí a mulher. Avalie nesse tempo, Ave Maria! Que não tinha justiça não... Os pais obrigava, tornava das mãe de 10 anos, de 12 anos, pronto para eles, eles diziam que eram o dono na dormida, você tá entendendo? no quarto, na cama que eles dormiam com elas. Não tinha moça não senhor. Sofria...”

Raquel

Férias/Magalhães de Almeida

"No tempo bom que eu ainda alcancei as moças tinha medo do homem. Não tô dizendo para você, que no tempo da malvadeza elas iam chorando? Ave Maria! Não gosto de falar, patrão, que eu me lembro, se fosse eu, eu morria também. Dela ir dormir mais o homem sabendo que... Ave Maria! Quando era bem cedo... Papai contava tudinho. Eu não conto para você porque Dona Maria tá aqui, e que eu respeito, mas chegava cheia de sangue de rasgada da coisa dos homens... Isso era dos rico do tempo do cativeiro, que não ia para rua para não pegar doença do mundo como tem deles que ainda alcancei quase tem acabado de comido, com a coisa comida daquela doença. Ave Maria! Ave Maria! Ave Maria! Chama cancro. Onde você mora não tem isso, não? Mas o homem não passa sem mulher. E nenhuma mulher passa sem homem. Aqui tem mãe que nem respeita as filhas... Os lagoanos ${ }^{11}$ são fogosos. Nesse tempo tavam a mulher mais marido conversando ali quando dava fé agarrava a mulher e carregava no ombro..."

Raquel

Férias/Magalhães de Almeida

A relação inversa era tão inevitavelmente reprimida como a primeira era cotidiana, conforme atesta a seguinte história do Baixo Parnaíba:

"O meu avô contou para minha mãe: A filha do dono do Arraial (segundo outra versão o dono dessa fazenda de escravos era o Capitão Gentil) gostou de um negro. Quando foi descoberta ela já estava buchuda. Aí ele mandou chamar o padre no brejo, encapuzado para ele não saber aonde ia. Mandou cavar a sepultura dentro do quarto e ajuntou a filha dele com o escravo barriga com barriga, amarrado. Disse pro padre: 'É para você confessar os dois

${ }^{11}$ Habitante da Lagoa do Bacuri. 
marmanjo.' Enterraram os dois vivos, em pé. Botaram barro arriba e o outro batendo. Segundo outra versão, o padre, na hora de sair, lembrou de contar os degraus da escada: eram sete. E como só tivesse a casa grande do Arraial com sete degraus, o padre descobriu onde ele tinha ido. Mas o pai nunca teve nada (não sofreu perseguição)".

Raimunda Pio

Fazendinha/Santa Quitéria

Aparece, nessas concepções racistas de "sujar o sangue" toda a esquizofrenia senhorial: o senhor podia "sujar o sangue" mas a senhora não podia... $\mathrm{O}$ resultado mais tangível foi, no imediato, o amulatamento das crias das escravas e o ressecamento do hímen das iaiás:

"Velho Castro teve 21 fêmeas. Só filha. Casou só uma..."

Raquel

Férias/Magalhães de Almeida

"Em Perizes de Cima tinha a fazenda de escravos dos mesmos Rocha. Ainda tem a imagem de Nossa Senhora da Conceição. As filhas do Rocha não casaram. Todas ficaram moça velha e loucas.”

Dedé Matos

Rosário

É importante ter em mente esta realidade do tempo do cativeiro, herança que ainda hoje pesa sobre as relações sexuais no Maranhão, para assim poder apreciar com mais circunstância as versões da "honra ofendida" do Balaio como razão da Balaiada.

A memória oral no Maranhão falava de maneira constante em senhores "bons" e "ruins". Pareceu-me, na época, importante procurar entender melhor esta distinção, pois não me convencia a visão, frequente na biografia senhorial, de que, evidentemente, havia os senhores sádicos, mas havia também aqueles que eram tão bonzinhos, que eram verdadeiros pais para seus escravos. Essa dicotomia do bom senhor/mau senhor também estrutura as narrativas da memória oral do cativeiro no Sudeste. Para Ana Lugão e Hebe Mattos, expressa uma "ética de tipo paternalista" que "organiza as possibilidades de afirmação social dos narradores". Assinalam, ainda, que "as narrativas de torturas 
e maus-tratos se fazem em geral como histórias genéricas, com personagens não identificados aos ascendentes do narrador". ${ }^{12}$

É certo que, no Maranhão também, era mais comum ouvir comentários positivos sobre os senhores dos próprios antepassados escravizados. Mas, como já assinalei, as genealogias nem sempre separavam tão nitidamente descendentes de escravos e de senhores, refletindo talvez um maior grau de "caboclização", no sentido da formação de um campesinato "pós-plantation" nessa província. Além do mais, no Maranhão, quando as pessoas lembravam do cativeiro em 1982, sempre falavam do cativeiro local, de referência mais imediata, dando nomes (por exemplo, a fazenda tal onde os antepassados foram escravizados) e do cativeiro regional (as fazendas circunvizinhas mais importantes das quais tinham notícia), sempre catalogando estes e aqueles senhores de "bons" ou "ruins". Ou seja, as narrativas de maus-tratos podiam também ser identificadas com os ascendentes do narrador.

O que foi o senhor "ruim" ou "malvado" não precisa ser explicado depois do exposto acima. O que foi então um senhor "bom"? Um critério sempre usado é o fato de não ter sido abandonado por seus escravos após a abolição.

"Alcancei meus pais e avós. Meu avô por parte de pai era o Carreta, dono de escravidão. A avó era Anastácia, escrava e rapariga dele. Ela é mãe do João Garé, que foi meu pai. Por parte de mãe, a avó era escrava dos Ferro, Filomena Maria da Conceição. O avô era Delfino José de Souza, liberto. Esse meu avô tocava tambor. Mataram ele de 'porcaria' (feitiço). No dia da abolição só os escravos do meu avô não o largaram e também os do finado Ferro e do Lázaro José de Carvalho. Mas os escravos nas [outras] fazendas largaram. Os Leite, Ricardo e muitos outros foram largados porque eles eram ruim demais pros pretos. Os Leite e os outros surrava e depois metia navalha cortava e botava num banco e salgava. Os escravos ia judiado demais. Mas na feitoria do meu finado avô não morria de fome fazia até festa de tambor, como os Ferro."

\section{Lázaro}

Cachoeirinha/Nina Rodrigues

O raciocínio é claro: o senhor só podia ser bom, já que o escravo podia ir, se quisesse gozar a sua liberdade pelo mundo afora. A memória oral aqui talvez ignorou o peso dos costumes e da dependência econômica. Para onde iria um escravo velho quando da Alforria? O segundo critério usado é que os

${ }^{12}$ Lugão e Mattos, Memórias do Cativeiro, p. 52-53. 
senhores bons deixaram as terras para os escravos quando da Alforria, como ocorreu em diversos lugares.

"Senhores bons teve na Boavista, que era de um casal de portugueses. Tinha casa-grande, rampa e tudo. Eles foram pra Lisboa e deixaram pros escravos as terras."

Dedé Matos

Rosário

Mas a terra não tinha grande valor comercial naquela época, sobretudo terra sem mão de obra que a trabalhasse. Senhores "bons" eram também aqueles que faziam certas concessões aos escravos, como permitiam bater tambor ou davam um resguardo para as mulheres:

"Na Cachoeira tinha senhores bons. Escrava prenha não trabalhava um mês antes do parto".

Dedé Matos

Rosário

Estas pequenas concessões, porém, nunca foram contrárias ao interesse do senhor porque não afetavam a produtividade do escravo. No caso do tambor, podia funcionar como desabafo e contribuir para que os escravizados se conciliassem com a sua condição. Era uma concessão capaz de assegurar maior estabilidade ao sistema escravista. No caso do resguardo, era também do interesse do senhor, a longo prazo, pois a gestação de filhos fortes pelas escravas era igualmente vantajoso para o dono. Outro argumento é que o "senhor bom" não maltratava os seus escravos. Então a violência não seria cotidiana, como se afirmou, nas fazendas dos senhores "bons"?

Os próprios depoimentos de memória oral trazem respostas:

"Meu pai dizia: 'Eu conto o que eu vi. Mas eu não sofri. Já era perto da Alforria. Eu nunca apanhei, não fui judiado, tenho o corpo limpinho. Graças a Deus. Por isso eu acho que estou vivo - porque fui bem tratado. Tinha uma parte de senhor que era malvado demais. Tinha outra que não era, era malvado, mas era melhor. Os malvados cortava de faca, aleijava. Os outros não era malvado assim não. Não adoecia a pessoa. Tem deles que era cortado de faca, ia pro banco; os melhores só surrava de bolo. De palmatória. De palmatória apanhei demais. Todo mundo usava, até na escola se usa. É pros menino ter medo para não fazer erro (...) A coisa melhorou muito depois que acabou o cativeiro". 
Raquel

Férias/Magalhães de Almeida

Essa visão pode falar em senhores bons porque normaliza a violência cotidiana, pois justamente para o escravizado ela era a norma. Os depoimentos qualificam então de ruim somente aqueles que cometiam os sadismos acima descritos. Mas, no fundo, o escravizado sabia, como diz Dona Raquel, que todos eram "malvados", bem que tinha uns que "eram malvados, mas era melhor".

A memória oral registrou até senhores que não batiam, nunca:

"Esse branco diz que era muito bom. Não batia - e quando soube que algum outro preto apanhava, procurava comprá-lo. Às vezes o preto ia trabalhar, mas cansado de trabalhar no canavial, ele fugia. Aí os outros diziam ao feitor e esse mandava atrás e eles encontravam. Nesse tempo não tinha estrada e se escondiam pelos matos. Na Prata, o senhor vendia então esse escravo, porque não batia: 'Meu preto, tu não gosta de mim? Não quer ficar comigo? Qual o senhor que tu queres?' Aí ele vendia. E nem todos os senhores eram bons. Diz que tinha um sumidor nas barreiras, onde hoje é a Ilha Nova (Ivar Saldanha)".

Dudu

Rosário

Este senhor "bom", em vez de recorrer à violência diretamente, utilizava sutilmente a dos outros como ameaça. A venda do escravo como ameaça não era incomum e é atestada pela memória oral.

Mas ausência de taca não quer dizer ausência de violência, já que a exploração do trabalho também é uma violência. Em todo caso, permaneceu, na memória oral maranhense, a lembrança da sujeição que foi a escravidão:

"Um negro do cativeiro. Eles já tinham gritado a Alforria: era liberto. Ele tinha um cavalo. Ele foi encabrestar o cavalo que tava solto no pátio (campo liberto) da casa de Santa Catirina (nome da morada). Aí ele foi, o outro companheiro dele mais ele. Já tinha corrido de manhã até as cinco da tarde. Quando deu das cinco para seis, o companheiro disse: 'Rapaz, sabe cuma qui tu encabresta ele?' O outro: 'Cuma? 'Vamo gritar o cativeiro para ele: CATIVEIRO DE SANTA HELENA QUE TE PERSIGA NOITE E DIA!' Aí o cavalo virou-se e ficou em pé. Aí meteram o cabresto (Santa Helena era o cativeiro mais perseguido)".

Raimunda Pio

Fazendinha/Santa Quitéria 


\section{c) RESISTENNCIA}

A resistência do escravo era registrada em toda parte pela memória oral. Ela toma muitas formas, que vão do suicídio à malandragem, do apelo ao Divino ao mocambo na distante cabeceira de um riacho...

O suicídio é a resistência desesperada. Só com a própria morte o escravo conseguia se vingar do senhor, frustrando-o de sua mão de obra ou trazendo-lhe os problemas relacionados com a sua morte que, como se vê pelo depoimento abaixo, não iam além de grande despesa para o senhor:

"O meu avô Avelino David era dono de escravatura, a família dele toda tinha escravatura. Eles tinham feitoria nos Currais, no Poção, no São José e na Santa Maria. Essa última era do capitão Mano Demetri. O capitão tinha um negro que vivia fugindo da Santa Maria para São José. Ele fugia e o capitão mandava atrás. Uma vez mandou dar uma dúzia de bolos para ele. Aí o negro entrou num quarto da casa- grande, lá nos fundos, amarrou o reio de arrear bezerra na ripa e se enforcou. Aí tavam procurando ele, não encontraram. Acharam ele pelos urubus que estavam sentado em cima da casa. Ele já estava podrezinho, fedendo. Mandaram os outros escravos sepultar ele. Aí veio ao conhecimento dos Pires que estavam de cima [na política], meu tio estava debaixo. Aí ele foi preso. Ele era Capitão da Guarda Nacional e foi preso na sala livre (a pessoa não fica trancado nem amarrado). Gastou dinheiro de 100 novilha-vaca para a defesa, para ser absolvido. E ficou na casa dele não se chamando pires [peça que acompanhava a xícara], mas só xícara rasa [o pires] e xícara funda, de tanto ódio que ficou dos Pires".

Zeza

Mata Roma

Algumas vezes a vingança teve que esperar o fim do cativeiro:

"O dono da feitoria criava um escravo de estima, para tirar as botas, calçar o chinelo. Um dia esse escravo, segundo o dono disse, abusou da bondade do senhor e aí ele fez uma carta mandando ele ser vendido para outra feitoria. Ele vinha já com a roupa e uma espingardinha. O novo dono: 'Ah! negro safado! Amanhã tu tens que apanhar um tanto de algodão'. Como ele não soube dar a conta da tarefa: taca! Este rapaz então criou a ideia de matar o senhor. Todo dia o branco vinha assistir o trabalho. Quando o senhor trepou na porteira para assistir o serviço, o rapaz já tava de tocaia, atirou nele e matou. Depois ele foi sofrer tanto, que não tinha mais as carnes do lombo, o reio tirou tudo. Depois 
da Alforria ele quis matar o outro dono que vendeu. Chegou perto da casa dele no dia da visita da cova [visita do $7^{\circ}$. dia]: 'Ah, desgraçado, tu adivinhou!'”.

Raimundo Erre

São Benedito

"Quando o preto ficou liberto, gostava de botar um susto no branco. Falava perto da casa do branco ou deitava em cima do jirau como se fosse senhor: '50 negros pra cá, 50 negros pra trabalhar acolá. [O branco]: 'Oh Meu Deus! Esse negro me mata de coração!' Isso com zoadas nas latas velhas que ele carregava..."

Domingos Raposo

Timbiras

Suicidar-se ou assassinar o senhor, que equivalia ao suicídio quando descoberto, eram opções extremas. Se a relação de força o permitia, a "impertinência" era o primeiro grau da desobediência do escravo:

"A filha da velha Francelina Pires, chamada Siara, botava água no leite para vender, para aumentar. Vendia pro povo da vizinhança. A velha escrava Sebastiana sabia, mas não dizia nada. Aí o menino fillho da escrava também um dia descobriu. Aí ele foi dizendo pros cabocos: 'Dona Siara bota água no leite! Dona Siara bota água no leite!' Aí a Siara trancou o menino dentro de um quarto e meteu a peia. Aí a mãe do menino chegou e disse: 'Branca, Branca do Diabo, você bota água no leite, você bota água no leite, você bota água no leite e agora dê em mim!' E mesmo ela não fazia isso porque na época tava ela sozinha com um bando de escravo e a família tava pro Rio".

Benedito Alves

Vazantinha/Magalhães de Almeida

Neste caso, o isolamento da iaiá em meio aos cativos punha limites ao arbítrio da iaiá, espaço que logo foi aproveitado pela resistência escrava. Mas o escravo malandro é o personagem principal dos atos de resistência na plantação. A malandragem era uma estratégia de sobrevivência:

"Meu avô era Pio, o irmão dele era Matia. A iaiá deles, na Catirina, tinha uma burra muito especial, de estrebaria, que foi do finado marido dela. Aí eles foram para uma festa de tambor na Passagem Funda. Eles levaram a burra escondido da iaiá. Quando chegaram amarraram a burra na mata escondido. Pularam para dentro do tambor e foram brincar. Quando foi a primeira cantada do galo, Pio 
falou pro Matia: 'Vamo embora!' Foram para lá onde tava a burra. A cobra tinha matado ela. Pio: 'Matia o que é qui nós faz?' Matia: 'Nós amarra os quatro pé e nós caça um pau e nós leva para estribaria!' Assim fizeram. Da Catirina à Passagem Funda dá bem umas cinco léguas. De manhã: 'Iaiá! A burra de sinhô [do finado marido dela] tá morta'. [E Iaiá:] '- O meu filho que foi isso?' '- Iaiá, foi cobra.' '- Pois, vai chamar o carroceiro para levar pro mato.' '- Não senhora, se tem negro para levar nas costas!' Aí levaram de novo nas costas e levaram pro mato. Só quando ela morreu, que eles foram contar pros outros".

Raimunda Pio

Fazendinha/Santa Quitéria

Percebe-se toda ironia final dos dois escravos querendo carregar a mula e fingindo ser escravos zelosos que só pensam no bem da senhora, quando na realidade estão zombando dela. Foram recolhidas várias versões dessa história, muito difundida nos municípios de Brejo, Santa Quitéria e São Bernardo.

Esconder o que sabe é outra malandragem que podia beneficiar o escravizado:

"Contaram meus avós. Esse negro era escravo do senhor. Então ele criou muita raiva do negro. Quando foi um dia, ele perguntou ao negro, se o negro sabia ler. O negro disse que não sabia. Aí ele disse, bem, pegou um papel e fez uma carta mandando dizer assim: Aí vai esse negro para você prender ele e matar que ele é um ladrão, ele não presta. Aí o negro levou a carta sem saber de nada. Quando ele chegou no caminho, talvez tocado de Deus, ele vai e pensou: 'vou abrir para ver o que tem nesta carta'. Aí achou assim, leu tudinho e achou deste jeito. Aí ele pegou aquela carta, jogou fora e botou assim: 'Amado Compadre, aqui vai este portador para você me mandar tantos mil. Mande pelo mesmo portador'. Aí ele botou assim na carta, o negro botou. Aí quando ele chegou lá e entregou, o homem só fez sacar o dinheiro e entregou para ele. E ele no bolso e clap! [bate as palmas] Se mandou e nunca mais! Aí ele mandou pedir o dinheiro, o homem. Ele mandou dizer o tempo que tinha que receber. Um tempo longo, não sabe?, o negro, para não dar tempo de ir atrás. Aí ele foi simbora com o dinheiro, nunca mais, nunca mais. E o homem esperando, esperando. Nunca que lhe chegou aquele dinheiro. Até que o homem, o compadre dele, foi saber do dinheiro que ele tinha mandado pedir e nunca mais. Para ele não ficar zangado porque já fazia muito tempo e ele queria saber onde tinha ficado esse dinheiro. Aí ele disse assim: 'Desse dinheiro? Não sei desse dinheiro não'. Mandando dizer que era pra mandar tantos milhões. Aí ele disse assim: 'Ah nêgo! Ah nêgo! Se eu soubesse, eu tinha te dado o fim logo. Me enganaste aquele dizendo que não sabia ler'. Aí pronto." 
Francisca Rodrigues

Currais/São Bernardo

"O Légua Buji é um encantado que baixa no Terecô. ${ }^{13}$ Se sumia um boi de carro, o dono falava e batia nos negros. Eles: 'Não foi a gente, ioiô'. Tinha sido eles que tinham comido, os pretos da senzala vivia roubando. Eles suplicavam Légua para defender eles. Aí aparecia o boi de novo no curral. O dono achava que tava errado e aí pedia desculpa, parava de bater. Mas no outro dia, cadê o boi?? Tinha sumido de novo."

Domingos Raposo

Timbiras

Nesta última história já entra o divino. O apelo ao divino podia ser ou a aparição de um Santo protetor do escravo, ou a maldição milagrosa do senhor. São Benedito também teve uma encarnação local na Coroara:

"Era um menino pretinho que o Marcolino [dono da Caroara] criava. Ele era só para tirar capim pra cavalo e tratar da estrebaria. Quando foi um dia, outro menino disse para ele: 'Rouba para mim um pedacinho de carne e uma mão cheia de farinha que estou com fome'. Pois bem, quando ele foi tirar capim ele pega um pedaço de carne e uma mão cheia de farinha, porque ele podia tirar para ele. Aí ele tirou e foi levando. Quando foi saindo com a farinha e a carne já arrumada na ponta da camisa escondida e o cofo por cima para tirar o capim, veio o Patrão e disse: 'O que é isso que estás levando, Benedito?' '- Isso não é nada.' '-O que é isso?' - '-É um bucado de fulôres' '-Pois bota no chão!' Aí ele derramou no chão e virou fulôres. Voltou pro rapaz: 'Não deu para roubar'. E contou a história. '- Ó rapaz, teu poder vai ser tão grande! Benedito, Benedito, Deus ajude que eu saia desse sofrer.' No outro dia, de manhã, uma nêga foi entrando no quarto de Benedito. Quando entrou ele tava de mãozinha dada e o pescoço torto, já tinha virado imagem. A imagem é dessa altura [mostra mais ou menos um metro]. Hoje ele está na Parnaíba, porque os preto velho já se acabaram tudo. Duas moças velhas, Merinda e Mariquinha, levaram".

Raimunda Pio

Fazendinha/Santa Quitéria

Ao que parece esta festa de São Benedito era muito festejada na Caroara:

${ }^{13}$ Sobre esse personagem, ver Mundicarmo Ferretti, Encantaria de Barba Soeira: Codó capital da magia negra? São Paulo: Siciliano, 2001. 
"A festa de São Benedito da Caruara era em dezembro. Tinha a Capela do Santo. O Santo ia e vinha rodeando, quando chegava no pé do mastro fazia aquela festa. $O$ vestido dele era um chambre branco com um cordão de São Francisco e as mangas cheias de flores. Sacudia aquelas flores no pessoal em volta do altar. Cantavam: 'São Benedito vem cheio de mangas de flores...' e não me lembro mais do resto. O velho Marcolino Rodrigues, dono da Caruara, fazia esse festejo todos os anos. Tinha o salãozinho de dois andares para dançar lá em cima. Embaixo era o armazém. Os pretos dançavam na senzala. No salão dançava a família dele e a gente de Santa Quitéria".

Maria José Fausto

Mata Roma/Santa Quitéria

A maldição do senhor "ruim" ou "malvado" aparecia com frequência na memória oral. Atesta o sentimento de justiça dessa memória. Da morte o senhor também não escapava. A morte aparece então como a grande niveladora para o consolo do escravo. A maldição do senhor na morte é a inversão que pode, in extremis, compensar as injustiças sofridas pelo escravo e sustentar, assim, os valores éticos próprios ao mundo camponês da pós-abolição. É o senhor sumindo do caixão, ou os dedos dele se cobrindo de "panarismo", ou a rede nova que leva o defunto se rasgando:

"O Lopes era o dono da escravatura da Guabiraba. Dizem que era muito ruim pros escravos. Quando ele morreu queriam levar o corpo pro Brejo. Mais não foi. Não puderam levar não. Botaram ele numa rede nova, aí na Guabiraba. Quando chegava lá, arriba, na chapada, aí, a rede rasgava com ele, caía no chão. Tornava a buscar outra rede, botava ele, chegava dentro, tornava a rasgar. Enterraram ele aí mesmo, ali no Cocal. E porque a rede rasgava não sei que diabo era. Rasgava a rede nova com a pessoa morta dentro, devido aos pecados".

Avelino Gonçalves

Pereira/Mata Roma

"Na Frexeira do velho Domingos Curico foi uma escravidão dura... Dois escravos novos tava namorando dentro de casa. A velha, esposa do Domingo, descobriu. Aí cortou o cabelo e raspou à navalha a negra e deu uma pisa nela. Aí a negra saiu pro Bananal, se ajoelhou e pediu a Deus para a patroa ter uma filha de cabeça pelada. Aí ela teve duas de cabeça peladinha. E da velha secou o braço, só ficou com o couro em cima do osso.”

Manuel Caldeira

Caruara/Santa Quitéria 
A fuga podia ser individual ou coletiva:

"Felipe era escravo da fazenda do Zé Paulo. Não queria trabalhar. Ele roubava de noite carne, toucinho, farinha, sal e fósforo e ia pro mato num lugar chamado Romão. No mesmo lugar tinha uma grota dentro de um mato fechado onde tinha água o tempo todo. Lá era o lugar do escravo se esconder. Passava seis dias, oito dias só comendo o que roubava. Quando terminava um, ia roubar mais. Esse escravo foi preso, algemado pelo senhor dele, até que, enfim, morreu deixando a dita grota do lugar, Romão, com o nome dele, Grota do Felipe [no município do Brejo]".

Manuel Messejano

Milagres/Brejo

"É, Felipe era escravo dos Candoz. Fugiu para Catirina. Vieram apanhar ele aqui. Levaram ele amarrado em cinza de rabo de cavalo. Quando chegaram lá, deram muito nele.”

Raimunda Pio

Fazendinha/Santa Quitéria

O escravo fugitivo, isolado, sempre dependia do furto para sua sobrevivência. O quilombo, então, era uma solução que podia ser mais duradoura para se subtrair ao cativeiro:

"Um ia buscar os outros e de pouco aos poucos eles iam sumindo. Pulava de pedra em pedra para não deixar rastro. E o senhor: 'Ó! Cadê meus escravos?' Mandava o capitão-do-mato atrás deles. Quando o capitão-do-mato, pretão da fazenda, encontrava um centro escondido, longe nas matas, à beira dum rio com roças e bananas, ele olhava os pretos, os velhos, se tinha ferro. Os novos não tinha porque eram nascidos no quilombo. Aí levava tudo".

Domingos Raposo

Timbiras

O quilombola procurava se fazer esquecer. Por essa razão quilombos não descobertos não constam da memória oral. É o lado mais oculto do tempo do cativeiro. Em algumas comunidades negras, como na Santa Rosa (Município de Itapecuru-Mirim), por exemplo, existia a memória dos "negros do mato", ou seja, escravos da fazenda que haviam se substraído ao controle do feitor e 
viviam escondidos nas proximidades, com a ajuda de alguns cativos. Contudo, a memória oral registrava, sobretudo, a repressão aos quilombos. ${ }^{14}$

"O senhor deles [dos escravos] morreu. Aí ficou a senhora. Aí eles entenderam de largar ela, não sabe? Ganharam os matos, pra lá fizeram aquela aldeia dos negros. O Negro Velho que era o chefe da família. Aí, lá, eles quando de manhã, dizia: 'Dez vai fazer fogo, dez vai fazer café, dez vai fazendo o almoço [...] e dez fica com ele causa do capitão-do-mato, que era para guarnecer o Negro Velho. Então nessas alturas, o senhor, que a mulher tinha pedido para amansar os negros, já andava procurando eles. Aí pegaram o negro, o Negro Velho. Pegaram, levaram para casa amarrado. Chegaram lá, tiraram o couro do Negro Velho, espicharam e botaram bem na porteira do curral da fazenda do senhor deles que tinha morrido. Aí tinha escrito assim: 'Estás vendo aí o espelho? Se não quizeram também ficar espichado, como está esse aí, amansem e procurem a senhora de vocês, senão morrerão do mesmo jeito e o couro vai espichado'. Aí os negros com isto começaram a amansar e a chegar e ficar na casa da senhora." ${ }^{15}$

Francisca Rodrigues

Currais/São Bernardo

A história daqueles que conseguiam escapar definitivamente do cativeiro é muito difícil de ser reconstituída. Mas, na região aqui estudada, é raro um município onde não se encontrem alguns centros com nomes sugestivos, como Quilombo, Mocambo, etc. Da mesma maneira, sempre se tem notícias de algum centro isolado "onde só tem negros", mas que visivelmente não foi feitoria.

O quilombola podia virar camponês porque, ao lado do mundo da casagrande e da senzala, já existia, na época da Balaiada, um camponês livre com o qual ele procurava se confundir. (O capitão do mato, na história anterior, não precisava olhar se os velhos tinham ferro?) E é esse campesinato o principal ator da revolta dos Bem-te-vis, nome mais positivo que a memória oral deu a essa guerra civil. Os escravizados também tiveram um papel de destaque na revolta. Aos quilombolas já existentes nas matas de Codó, em 1838, foram se juntando mais escravos que aproveitaram a confusão para fugir. Quando

\footnotetext{
${ }^{14}$ Sobre quilombos no Maranhão, ver Gomes, A hidra e os pântanos; Aráujo, Insurreição de escravos; e Matthias Röhrig Assunção, "Quilombos maranhenses”. In: João José Reis; Flávio dos Santos Gomes (eds.), Liberdade por um fio. História dos quilombos no Brasil. São Paulo, Companhia das Letras, 1996, p. 433-466.

${ }^{15}$ Esta história foi contada por D. Francisca, descendente de uma família de senhores de escravos de Frexeira, no Baixo Parnaíba/PI.
} 
Cosme Bento das Chagas assumiu a liderança de dois ou três mil quilombolas, estes passaram a jogar um papel mais ativo na revolta, que assim também foi a maior insurreição escrava da história do Brasil, tanto pelo número de insurretos quanto pela dificuldade de serem derrotados, fato pouco assimilado pela historiografia sobre essa temática. Dom Cosme teve uma visão política excepcional e procurou a aliança com os bem-te-vis para lograr a liberdade para o seu povo. ${ }^{16}$ Infelizmente não encontrei registros significativos sobre ele na memória oral. O que as pessoas ainda lembravam, em 1982, eram episódios da guerra onde os escravos foram protagonistas.

Os balaios aparecem na historiografia tradicional como terríveis sanguinários que teriam cometido horríveis assassinatos, sem distinção de sexo nem idade. A memória oral também registrou vários casos célebres, como o de Antônio Rulindo Garreto, sangrado pelos Bem-te-vis:

"Teve um francês aqui, o Antonio Rulindo Garreto, instalou-se na Santa Rita. Tinha serraria, quartos cheios de algodão. Nessa mesma guerra tinha os preto revoltosos. Aí sangraram ele em 1838 (o irmão do meu sogro lembrava). Diz que tinha um quarto cheio de pluma de algodão. Uma moça da família se escondeu lá e, quando aliviou o movimento, ela estava quase morta. No Anapurus tem um cemitério de pedra. Uma velha me disse que aí tá o francês enterrado. Esse francês diz que correu da Vargem Grande e saiu no Tambor (nas cabeceiras do córrego Anapurus)".

Maria Garreto de Souza

Mata Roma

Mas quem era esse Rulindo? A seu respeito colheu-se o seguinte:

"Uma senhora que morava perto dos meus pais me contou: Antonio Rulindo Garreto pegava os preto, amarrava eles e botava em cima de um pau que pisava arroz. Aí mandava gritar que nem porco e sangrava eles. E ainda pegava mais as preta e preto, retalhava as nádegas, botava sal. Amarrava os pés e mãos e atravessava num pau e dependurava na chapada e ia de vez em quando olhar para ver se estavam vivos".

Raimundo Passos Montelles

Anapurus

\footnotetext{
${ }_{16}$ Sobre Cosme, ver Santos, A Balaiada; Araújo, Em Busca de Dom Cosme; e Matthias Röhrig Assunção, "Cabanos contra Bem-te-vis: A construção da ordem pós-colonial no Maranhão (1820-1841)”. In: Mary del Priore \& Flávio dos Santos Gomes (orgs.), Os senhores dos rios. Amazônia, margens e histórias, Rio de Janeiro, Campus, Elsevier, p. 195-225.
} 
Dois outros habitantes do município de Anapurus contaram versões parecidas, sempre associando a crueldade de Rulindo com o fim que os escravos revoltosos lhe deram. Uma versão ligeiramente diferente foi contada por seu Boaventura:

"O Bentinho Garreto, neto do Rulindo que me contou. Na Santa Rita tinha a feitoria do Rulindo Garreto. Ele tinha um genro que era muito malvado, chamado Faustino. Durante a guerra, vieram matar ele. Chegaram, ele pediu para comer primeiro. Botou a mesa, chamou os filhos, comeram. Aí o filho dele pegou uma imagem do Senhor, se ajoelhou no pé dos soldados: 'Por essa imagem, não façam isso a meu pai!' Eles responderam: 'Por essa imagem é que a gente faz! Porque ele era malvado'. Pediu para ler um pouco na rede. Pegou o livro. Tava lendo, quando tava no ponto: 'Pode fazer!' Nenhuma arma pegou fogo. Aí disseram: 'Tu é bom para bala, mas não é bom para faca e mataram ele de faca!'. O velho Rulindo caminhou pro Brejo, caçar recurso. Quando voltou, foi passar o rio Preto e, achando que não ia se molhar, atravessou em cima do burro embotoado, ele vinha suado. Aí a água entrou dentro das botas e estoporou ele".

Boaventura

Anapurus

Essa versão não muda a estrutura fundamental da narrativa, só a transfere para o sogro do Rulindo. Em ambos os casos aparece claramente que a violência revolucionária dos Bem-te-vis é nada mais que a resposta à violência da sociedade escravagista.

Perto da Manga teve o caso da escravocrata Don'Ana da Barra:

"Don'Ana da Barra (Barra do rio Munim com o Preto) foi se esconder nos morros do Anajá com um dos pretos dela pra fugir da guerra. Aí o preto saiu para mariscar (vir atrás de mulher), aí pegaram ele, e ele teve que ensinar aonde ficava Don'Ana. Aí foram matar ela, pegaram tudo dela que ela tinha carregado, jogaram ela dentro do poço e botaram o forno em cima”.

Francisco Martinho

São Roque/Vargem Grande

Outro caso famoso é o da portuguesa Eusébia Maria da Conceição, que a Enciclopédia dos Municípios Brasileiros chama a "principal povoadora do Brejo" e que "foi barbaramente morta, com 21 facadas, quando da Balaiada no dia 13 de maio de 1839, no lugar Gameleira-Piauí, pelo balaio Antonio Bem-te-vi, 
que com mais de nove companheiros, depois de deceparem-lhe a mão direita, trouxeram-na em troféu pelas ruas da vila além de roubarem suas joias e Rs $1.200 \$ 000$ em moedas de ouro". ${ }^{17}$ Segundo a memória oral, menos puritana que as enciclopédias, não foi bem a mão que levaram em troféu para o Brejo, foram as partes genitais:

"A Euzeba Maria, era chamada de Dona Cabana. Esticaram a coisa dela pro Severino olhar".

Januária

Almas/Brejo

Euzébia Maria era a sogra do odiado prefeito do Brejo, Severino Alves de Carvalho, que logo no início da guerra fugiu para Parnaíba. Essa poderosa escravocrata tampouco era isenta de crueldade:

"O velho Hortêncio, contando da velha Euzeba. Vinha um senhor tomando, por nome Antonio João mandou avisar que chegasse. Ela se valeu do Timóteo para salvar a situação no Brejo. Se esconderam e, quando veio a turma do Antonio João - ele vinha bem na frente, aí o Timóteo fez fogo nele com os três filhos. Aí a Euzeba pisou na cabeça dele e dizia: 'Antonio João, tu é que vinha para acabar com o Brejo!"”.

Zeca Lotide

Macambira/Buriti

Já foi descrito como se "espichou o couro" de um negro aquilombado. Mais uma vez, nos parece que o fim dado a Euzébia Maria se inscreve no capítulo das vinganças pessoais contra os potentados escravocratas mais odiados da região.

Esses depoimentos demonstram, a meu ver, que a violência dos escravizados revoltados e dos Bem-te-vis não era cega nem indiferenciada. Pelo contrário, se dirigia contra aqueles prefeitos e donos de escravatura que tinham reconhecidamente praticado crueldades contra os cativos ou contra a população livre pobre. Nesse sentido, não foi uma violência primeira, foi uma reação contra outras violências, anteriores. A Balaiada representa assim um autêntico momento de revolução, onde o perseguido de ontem vira perseguidor e viceversa: quem sangrava seus escravos é sangrado, quem "espichava o couro" é espichado também. Os Bem-te-vis não fizeram nada mais do que satisfazer as

${ }^{17}$ Rio de Janeiro, IBGE, 1957, verbete "Brejo". 
aspirações de justiça das classes mais oprimidas da sociedade. Pena de talião, sem dúvida, mas havia outra opção numa sociedade em que a justiça ainda era subjugada aos interesses dos senhores de escravos?

A memória oral do cativeiro no Maranhão é assim como uma janela oferecendo uma perspectiva privilegiada sobre a realidade concreta da escravidão nessa província. No primeiro plano dessa memória vêm as histórias de vida dos antepassados diretos da família, compartilhadas apenas por um número reduzido de pessoas. No meio de campo, com mais visibilidade, a memória oral das comunidades, sobretudo daquelas assentadas em "terras de preto". Sua origem legitima a posse e, junto aos episódios do seu desenvolvimento, tem a função de reforçar os laços entre seus membros e a sua coesão interna. Finalmente, no pano de fundo, uma memória regional, episódios que são relatados em vários municípios. A perspectiva da memória oral não é neutra nem objetiva, mas exprime de maneira emocionante todo o sofrimento dos ancestrais escravizados, incluindo o estupro das escravas (ainda hoje negado por alguns políticos anticotas), e a maldição aos seus torturadores - os "malvados". Em alguns aspectos também espelha, de maneira ambígua, a incidência do paternalismo ainda vigente até hoje no interior do estado. Mas como vimos, a dicotomia entre o bom e mau senhor é bem mais sútil do que parece à primeira vista, e as perspectivas da memória oral não são tão monolíticas. O interesse dessa memória, então, reside na sua incomparável força poética de expressão, na sensibilidade com a qual retrata o cotidiano do cativeiro, e nos múltiplos detalhes que permitem reconstruir com mais acerto essa experiência singela, e ainda insuficientemente assimilada pela historiografia tanto brasileira quanto internacional, da escravidão dos africanos e de seus descendentes no Maranhão. 